\title{
Quality Maintaining of Stored Cucumbers Under Cold Stress and Shelf Life at Room Conditions by Integrating Calcium Chloride and Short Hot Water
}

\author{
Ibrahim N. Nasef \\ Department of Horticulture, Faculty of Agriculture, Suez Canal University, 41522, \\ Ismailia, Egypt.
}

\begin{abstract}
CUCUMBER fruits were impregnated inhot water at $55^{\circ} \mathrm{C}$ for 5 min containing 0,1 or $2 \%$ calcium chloride to study the effectiveness of the integration of calcium chloride and short hot water in prompting cold stress tolerance and quality maintenance of cucumbers during cold storage and room conditions. The quality attributes like weight loss, appearance, color, taste, chilling injury, firmness, soluble solids content, sugars and total phenolics, electrolyte leakage and antioxidant enzymes (peroxidase and catalase) were analyzed during cold storage for 7, 14 and 21 days at $4{ }^{\circ} \mathrm{C}$ and shelf life at room conditions for 2 and 4 days. The combined treatment of $1 \%$ calcium chloride andshort hot water $(1 \% \mathrm{Ca}+\mathrm{SHW})$ exhibited a significant synergistic enhancement in inducing chilling tolerance, degrading peroxidase activity, maximizing catalase activity and reducing electrolyte leakage. Likewise, a good appearance, better taste and color,less weight loss and highest firmness and total phenolicswere documented in $1 \% \mathrm{Ca}+\mathrm{SHW}$ treated cucumbers. SSC and sugars were preserved by inhibiting ripening and senescence processes in $1 \% \mathrm{Ca}+\mathrm{SHW}$. In the light of this study, $1 \%$ calcium chloride in combination with short hot water as a commercial applicationcan be used to maintain quality,increase storability and extend cold storage of cucumbers at $4{ }^{\circ} \mathrm{C}$ and shelf life at room conditions or at the market and home.
\end{abstract}

Keywords: Cucumis sativus, $\mathrm{CaCl}_{2}$, Quality, Shelf life, Chilling tolerance, Antioxidant enzymes.

\begin{abstract}
Introduction
Cucumber (Cucumis sativus L.) is a main vegetable grown in Egypt, and holds a major position in market of vegetables. It is eaten as fresh vegetable which is an excellent sourceof vitamin K, lignans, flavonoids, Triterpenes, antioxidants and minerals (Maheshwari et al., 2014). Cucumbers have a very low calorie, and contain no cholesterol or saturated fats. The consumption of cucumbers may reduce the risk of aging and skin discoloration, cancerous and cardiovascular diseases and inflammations, and supportthe bone strength. Additionally, cucumbers can be used to treat sunburns and wrinkles and used as a skin brightener and moisturizer (Murad and Nyc, 2016). Usually, consumer judges the cucumber quality on the basis of freshness and appearance at the purchase time. Cucumbers are a highly perishable commodity and susceptible to low temperatures below $7^{\circ} \mathrm{Cwhichresults} \mathrm{ina} \mathrm{lot}$ of biochemical and physiological processes such
\end{abstract}

as water loss, surface pitting, discoloration, cell wall degradation, membrane damage, production of reactive oxygen species andripening and senescence (Hakim et al., 1999 and Tsuchida et al., 2010), particularly when the temperature is raised after exposure to low temperature (Manjunatha and Anurag, 2014). These processes deteriorate the quality and shorten shelf life of cucumbers. Therefore, hot water treatments were used as safe treatment to maintain quality of cucumbers (Nasef, 2018), peach (Huan et al., 2017), kale and collard (Wang, 1998). Similarly, calcium chloride was used as eco-safe compound in preserving quality of papaya (Lata et al., 2018), and persimmon (Bagheri et al., 2015). Calcium plays a crucial role in quality of fruit and vegetables. It reduces physiological disorders and chilling injury, improves firmness, delays softening and retards ripening and senescence by strengthening cell walls, stabilizing cell membrane and inducing antioxidant enzymes (Chen et al., 2011 and Bagheri et al., 2015). Recently, the

Corresponding author:Ibrahim N. Nasef, e-mail: innasef@hotmail.com

DOI:10.21608/ejoh.2018.6496.1089

(C)2019 National Information and Documentation Centre (NIDOC) 
use of combined treatments in the commercial practices to maintain quality fruit and vegetables has been successfully applied. Application of combined treatments may lead to less dependence on refrigeration of perishable products during handling, thus reducing energy which is required in local and short-distance distribution chains (Toivonen, 2009). In this respect,calcium in combination with heat treatments reduced decay and maintained quality of apples (Conway et al., 1994), preserved fresh-cut apple (Aguayo et al., 2015), improved physicochemical and physical parameters of kiwifruit (Shahkoomahally and Ramezanian, 2015), controlled microbial growth in fresh-cut melon (Silveira et al., 2011), improved firmness of strawberry (Shafiee et al., 2010), delayed the anthracnose symptoms and improved the quality of papaya (Ayón-Reyna et al., 2017). However, there is no report on combination of calcium chloride and hot water on cucumbers quality during storage under cold stress. Additionally, no information isavailable about the quality attributes of cucumbers during shelf life at room conditions after cold storage. Consequently, this study aimed to investigate the effect of calcium chloride combined with hot water onweight loss, appearance, color, taste, firmness, SSC and sugars, total phenolic, chilling injury, electrolyte leakage andperoxidase and catalase activity during cold storage and shelf life at room conditions.

\section{Materials and Methods}

Plant materials, treatments and storage conditions

Cucumber fruits cv. Dahshan were harvested on January 29, 2017 in the first season and on January 21, 2018 in the second season from a commercial organic farm under greenhouse in Elkassaseen, Ismailia, Egypt. Fruits were delivered within one hour to the Laboratory of Horticulture Department, Faculty of Agriculture, Suez Canal University, Ismailia, Egypt. Fruits wereselected for uniform length, shape and color. The fruits were split to three groups, each contains 108 fruits. The first group was impregnated in water at $55^{\circ} \mathrm{C}(0 \%$ calcium chloride $)$ as a control (SHW). The second group was impregnated in 1\% calcium chloride solution at $55{ }^{\circ} \mathrm{C}(1 \% \mathrm{Ca}+\mathrm{SHW})$. The last group was impregnated in $2 \%$ calcium chloride solution at $55{ }^{\circ} \mathrm{C}(2 \% \mathrm{Ca}+\mathrm{SHW})$. The three treatments were impregnated for short term of $5 \mathrm{~min}$. The fruit surface moisture was directly dried after treating by fan. Fruits were cooled for $30 \mathrm{~min}$ at ambient room temperature.
After drying, four fruitswere considered as one replicate, then were put into polystyrene foam dish, andthen were wrapped by film of highly perforated polyethylene, treated cucumbers were then stored for 7,14 and 21 days at $4{ }^{\circ} \mathrm{C}$ with 85 $90 \%$ of humidity. After cold storage, cucumbers were transferred to room conditions $\left(22-24{ }^{\circ} \mathrm{Cand}\right.$ $60-65 \% \mathrm{RH})$ for 2 and 4 days.

\section{Measurements \\ Weight loss}

The weight loss of four cucumber fruits in each replicate were weighted before the storage as an initial weight and then were weighed during cold storage and shelf life at room conditions. The weight loss was calculated as a percentage from the initial weight.

\section{Appearance}

Five panelists with experience in sensory evaluations assessed cucumber appearance during cold storage and shelf life at room conditions. Appearance was rated on a scale of $1-9$, where9= excellent (fresh appearance), $7=$ very good, $5=$ good (limit of marketability), 3= fair (limit of usability), and $1=$ poor (inedible) (Koukounaras et al., 2008).

\section{Hue angle}

Fruit color was estimated using a Hunter colorimeter (HunterInstrument DP-9000, Japan) which measures $a^{*}\left(+a *\right.$ indicatesredness, $-a^{*}$ indicates greenness $)$ and $b^{*}\left(+b^{*}\right.$ indicates yellow, $-b^{*}$ indicates blue), the $a^{*}$ and $b^{*}$ values were transformed to hue angle using the following equation: $\mathrm{h}=\tan ^{-1}\left(\mathrm{~b}^{*} / \mathrm{a}^{*}\right)+180$ (Trail et al., 1992).

Taste

Panelists rated the cucumber taste on a scale of 5-1, where: $5=$ fully typical, $4=$ moderately full, $3=$ moderate, $2=$ slight and $1=$ none (Elwan et al., 2015).

\section{Chilling injury}

Chilling injury was rated visually by the surface pitting, the affected surface area was evaluated asa percentage on a scale of 1-5, where 1 refers to no injury, 2 to slight (up to $20 \%$ ), 3 to moderate $(21-40 \%), 4$ to moderately severe (61-80\%), 5 to severe (81-100\% of affected area) (Imahori et al., 2008).

\section{Firmness}

Cucumber firmness was estimated at the equator of fruit using the pressure tester (FT 011, Italy), at speed of $50 \mathrm{~mm} \mathrm{~s}^{-1}$ with $8 \mathrm{~mm}$ plunger. 


\section{SSC and sugars}

Soluble solids content (SSC) of cucumbers was measured using a hand refractometer (Atago N1, Japan), and expressed as \%. Total sugars were determined spectrophotometrically at $480 \mathrm{~nm}$ according to Dubois et al. (1956). Reducing and non-reducing sugars were determined according to Sadasivam and Manickam (1991).

\section{Total phenolics}

Total phenolics were measured using a spectrophotometer (UNICO UV/Visible 2100, USA), as described by Sadasivam and Manickam (1991).

\section{Electrolyte leakage}

Electrolyte leakage was estimatedin cucumbers after removal from cold storage and after shelf life at room conditions. Five disks (7 $\mathrm{mm}$ diameter and $3 \mathrm{~g}$ ) were excised from fruit mesocarp tissue using a cork borer (Hakim et al., 1999). The disks were soaked in $50 \mathrm{~mL}$ of double distilled water at $25{ }^{\circ} \mathrm{Cin}$ glass conical flask. One hour later, the electrical conductivity was estimatedto evaluate initial conductivity (EC1) by a digital electrical conductivity meter (CD4301, LutronInst.Co. UK), the disks were then boiled for tenminutes, and total conductivity was estimated (EC2) to determine $100 \%$ electrolyte leakage.Electrolyte leakage was calculated as percentage using the following equation: (EC1/ EC2) $\times 100$ (Huan et al., 2017).

\section{Peroxidase activity}

Peroxidase activity was determinedaccording to Sadasivam and Manickam (1991). The activity was calculated as unit per kilogram per second of fresh weight $\left(\mathrm{U} \mathrm{kg}^{-1} \mathrm{~s}^{-1}\right)$.

\section{Catalase activity}

Catalase activity was analyzed according to Goth (1991). The activity of catalase was calculated as unit per kilogram per second of fresh weight $\left(\mathrm{U} \mathrm{kg}^{-1} \mathrm{~S}^{-1}\right)$.

\section{Statistical analysis}

The experiment was planned in a completely randomized block design (CRBD) with a split plot, with three replicates. The treatmentswere randomly distributedin the main plots and the cold storage periods were randomly distributed in the sub plots. The data of experiment were achieved by analysis of variance(ANOVA) by Co Stat version6.303 1998-2004, Co Hort software,798 Lighthouse Ave, PMP320, Monterey, CA 93940, USA. Sigma Plot10.0 software (Systat Software Inc., Hounslow, UK) was used to calculate the standard error of means for illustration in the figures.

\section{Results}

\section{Weight loss}

$1 \% \mathrm{Ca}+\mathrm{SHW}$ had the lowest weight loss incomparison with $\mathrm{SHW}$ and $2 \% \mathrm{Ca}+\mathrm{SHW}$ in both seasons (Fig. 1). The weight loss increased continuously with increasing thestorage time. During the cold storage at $4{ }^{\circ} \mathrm{C}$ plus shelf life at room conditions, $1 \% \mathrm{Ca}+\mathrm{SHW}$ lost 12.33 and $11.02 \%$ of fruit weight in the first and second seasons, respectively, while SHW 13.28 and $13.03 \%$, and $2 \% \mathrm{Ca}+\mathrm{SHW} 14.34$ and $14.16 \%$ in both seasons, respectively.

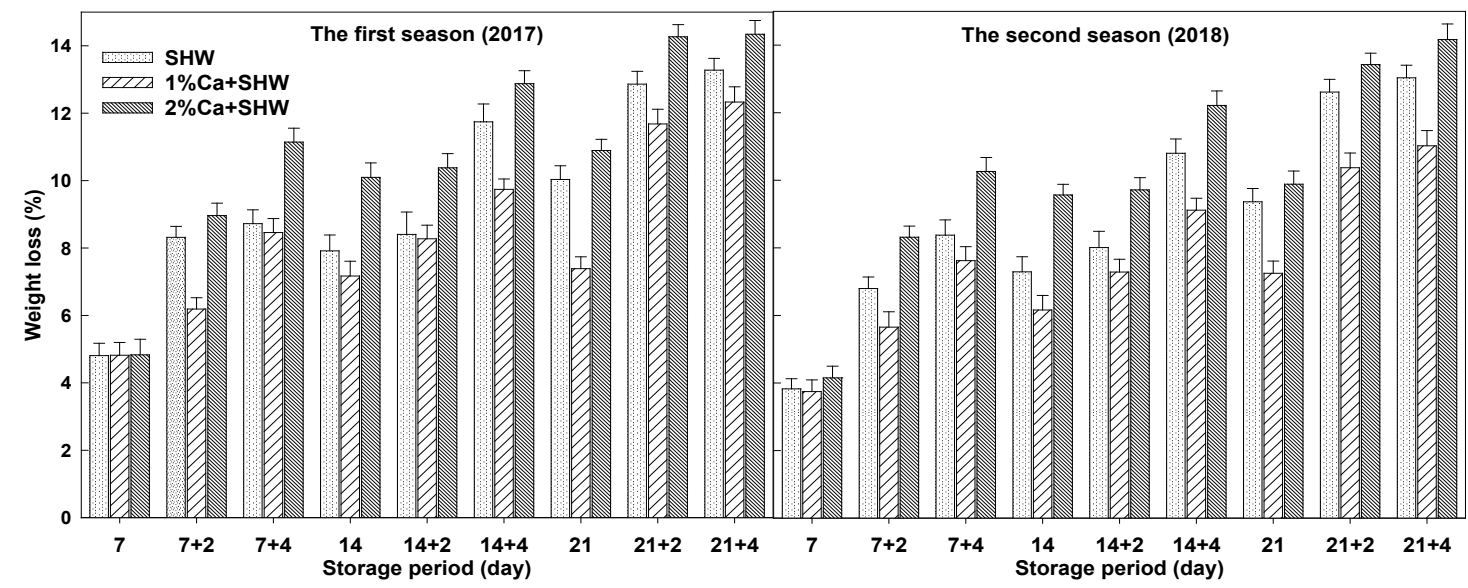

Fig.1. Effect of calcium integrated with hot water treatments on weight loss of cucumbers after cold storage at $4{ }^{\circ} \mathrm{C}$ and shelf life at room conditions. Values are the mean of $n=3$ and vertical bars indicate the standard error. $\mathrm{SHW}=$ short hot water at $55^{\circ} \mathrm{C}, 1 \% \mathrm{Ca}+\mathrm{SHW}=1 \%$ calcium chloride solution at $55{ }^{\circ} \mathrm{C}, 2 \% \mathrm{Ca}+\mathrm{SHW}=1 \%$ calcium chloride solution at $55^{\circ} \mathrm{C}$. 
Appearance

$1 \% \mathrm{Ca}+\mathrm{SHW}$ had the highest value of appearance compared with SHW and $2 \%$ $\mathrm{Ca}+\mathrm{SHW}$ in both seasons. The appearance of $1 \%$ $\mathrm{Ca}+\mathrm{SHW}$ treated fruit after 14 days at $4{ }^{\circ} \mathrm{C}$ plus 4 days at room conditions were scored as very good compared with SHW and 2\% $\mathrm{Ca}+\mathrm{SHW}$ which were scored as good (Fig. 2). However, at the end of cold storage and shelf life, $2 \% \mathrm{Ca}+\mathrm{SHW}$ treated fruit were scored as fair (limit of usability), while SHW and $1 \% \mathrm{Ca}+\mathrm{SHW}$ were scored as good (limit of marketability) in both seasons.

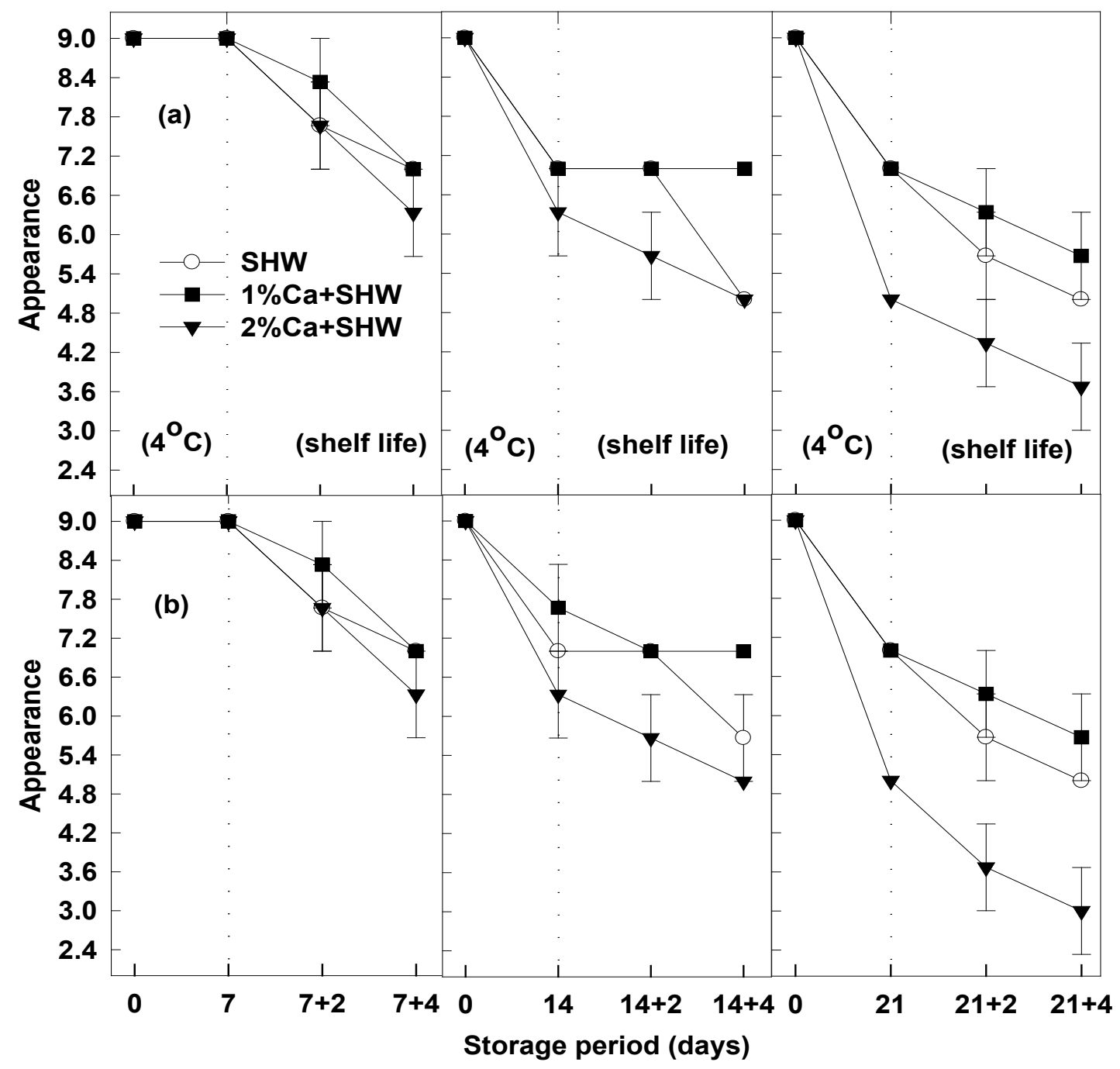

Fig.2. Effect of calcium integrated with hot water treatments on appearance of cucumbers after cold storage at $4{ }^{\circ} \mathrm{C}$ and shelf life at room conditions. a, the first season, $b$, the second season. Values are the mean of $n=3$ and vertical bars indicate the standard error.SHW $=$ short hot water at $55^{\circ} \mathrm{C}, 1 \% \mathrm{Ca}+\mathrm{SHW}=1 \%$ calcium chloride solution at $55^{\circ} \mathrm{C}, 2 \% \mathrm{Ca}+\mathrm{SHW}=1 \%$ calcium chloride solution at $55^{\circ} \mathrm{C}$.

\section{Hue angle}

Hueangle of cucumbers was lowest in $2 \%$ $\mathrm{Ca}+\mathrm{SHW}$ treatment in both seasons. However, non-significant difference was observed between SHW and $1 \% \mathrm{Ca}+\mathrm{SHW}$ in the first season. Hue angle decreased significantly $(\mathrm{p} \leq 0.001)$ with prolongation of cold storage period at $4{ }^{\circ} \mathrm{C}$ and shelf life at room conditions (Fig.3). At the end of storage, $1 \% \mathrm{Ca}+\mathrm{SHW}$ had the highest hue angle compared with SHW and $2 \% \mathrm{Ca}+\mathrm{SHW}$ in both seasons. 


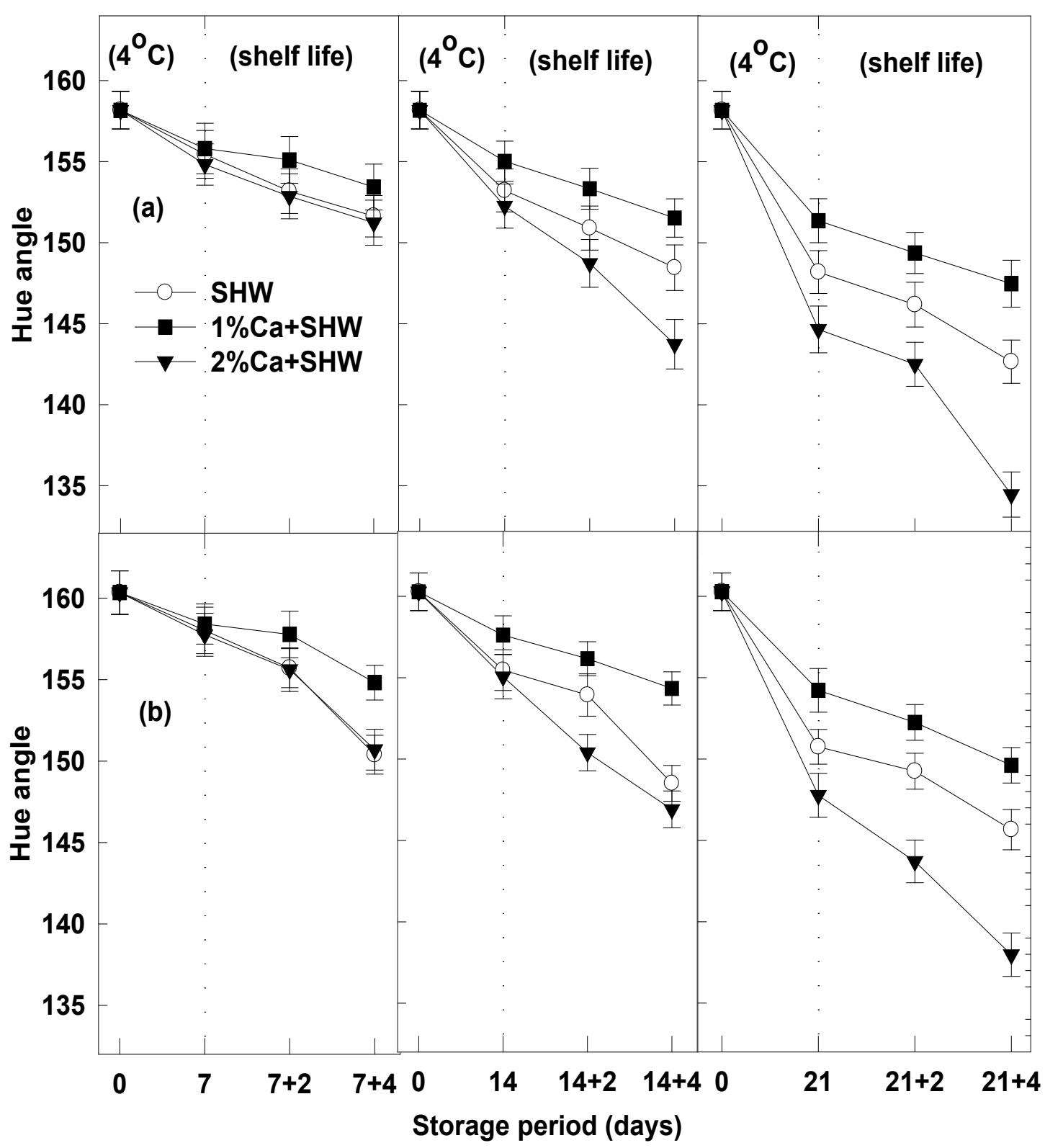

Fig. 3. Effect of calcium integrated with hot water treatments on hue angle of cucumbers after cold storage at $4^{\circ} \mathrm{C}$ and shelf life at room conditions. a, the first season, $\mathrm{b}$, the second season. Values are the mean of $\mathrm{n}=3$ and vertical bars indicate the standard error. $\mathrm{SHW}=$ short hot water at $55^{\circ} \mathrm{C}, 1 \% \mathrm{Ca}+\mathrm{SHW}=1 \%$ calcium chloride solution at $55{ }^{\circ} \mathrm{C}, 2 \% \mathrm{Ca}+\mathrm{SHW}=1 \%$ calcium chloride solution at $55{ }^{\circ} \mathrm{C}$.

Taste

$1 \% \mathrm{Ca}+\mathrm{SHW}$ treated fruit had the highest taste score compared with SHW and $2 \% \mathrm{Ca}+\mathrm{SHW}$ in both seasons (Fig. 4). Cucumber taste reduced with increasing cold storage and shelf life at room conditions. At the end of storage time, taste of $1 \%$ $\mathrm{Ca}+\mathrm{SHW}$ treated fruitswas scored as moderately full while SHW treated fruits were scored as moderate and $2 \% \mathrm{Ca}+\mathrm{SHW}$ treated fruits were scored as slight in both seasons. 


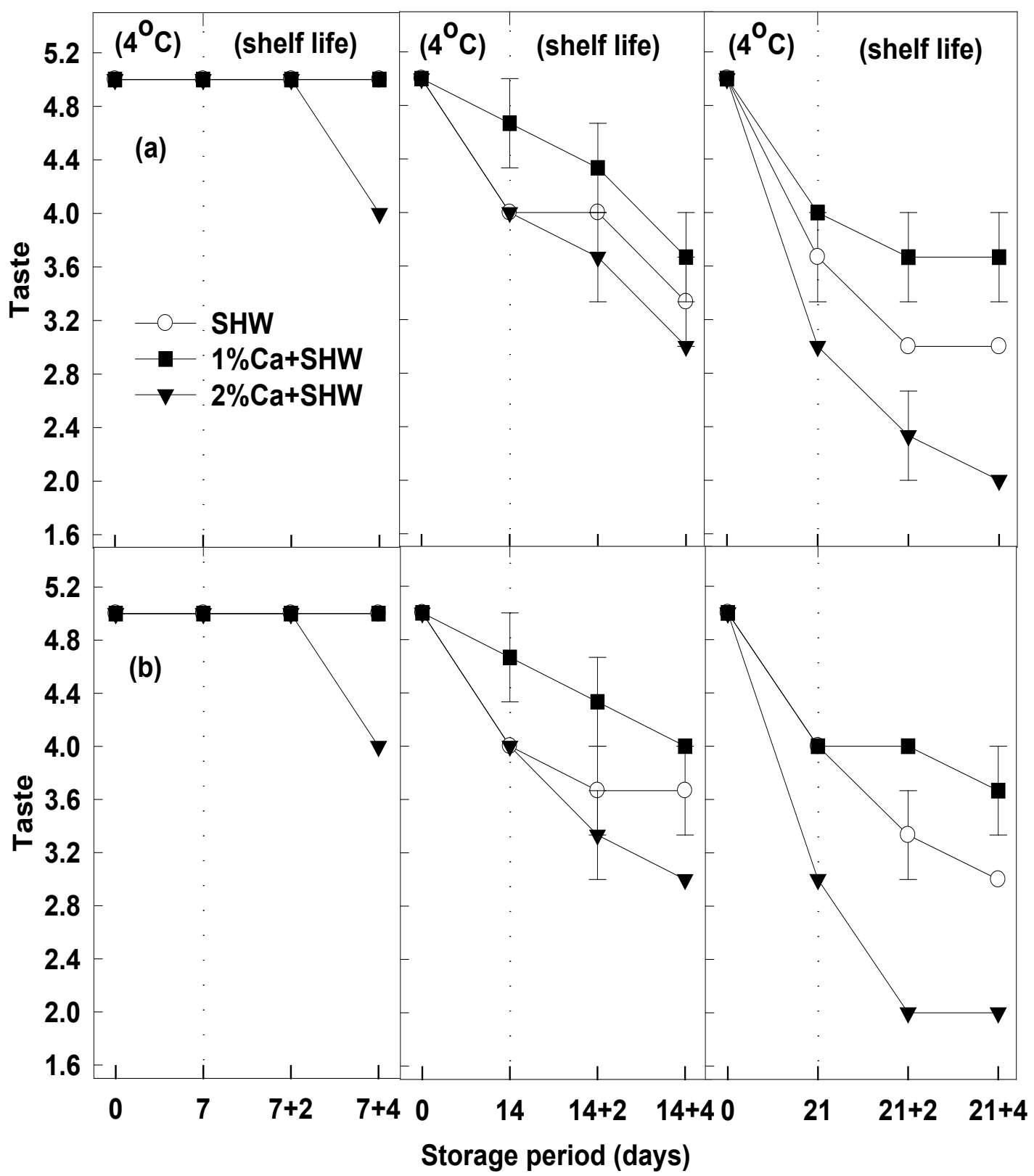

Fig. 4. Effect of calcium integrated with hot water treatments on taste of cucumbers after cold storage at $4{ }^{\circ} \mathrm{C}$ and shelf life at room conditions. a, the first season, $b$, the second season. Values are the mean of $n=3$ and vertical bars indicate the standard error.SHW= short hot water at $55{ }^{\circ} \mathrm{C}, 1 \% \mathrm{Ca}+\mathrm{SHW}=1 \%$ calcium chloride solution at $55{ }^{\circ} \mathrm{C}, 2 \% \mathrm{Ca}+\mathrm{SHW}=1 \%$ calcium chloride solution at $55{ }^{\circ} \mathrm{C}$.

\section{Chilling injury}

During the initial 7 days of storage at $4{ }^{\circ} \mathrm{C}$ plus 4 days at room conditions, no pitting was detected in the three treatments. $1 \% \mathrm{Ca}+\mathrm{SHW}$ treated fruits had the same scores in both seasonsduring the cold storage and shelf life at room conditions. At the end of storage period, $1 \% \mathrm{Ca}+\mathrm{SHW}$ treated cucumbers had the lowest chilling injury followed by SHW while $2 \% \mathrm{Ca}+\mathrm{SHW}$ had the highest chilling injuryin both seasons (Fig.5). 


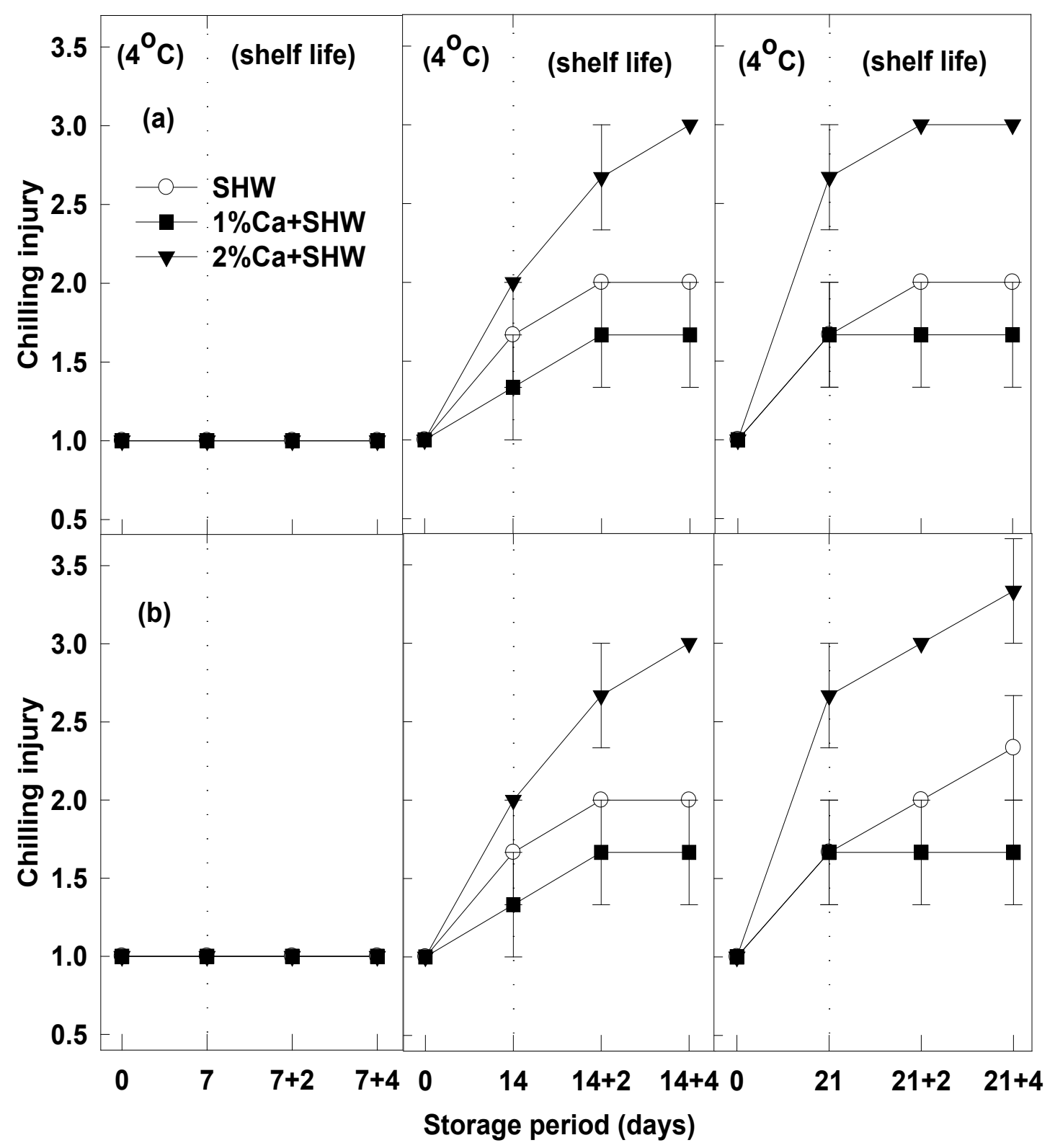

Fig.5. Effect of calcium integrated with hot water treatments on chilling injury of cucumbers after cold storage at $4{ }^{\circ} \mathrm{C}$ and shelf life at room conditions. a, the first season, $b$, the second season. Values are the mean of $n=3$ and vertical bars indicate the standard error.SHW $=$ short hot water at $55^{\circ} \mathrm{C}, 1 \% \mathrm{Ca}+\mathrm{SHW}=1 \%$ calcium chloride solution at $55^{\circ} \mathrm{C}, 2 \% \mathrm{Ca}+\mathrm{SHW}=1 \%$ calcium chloride solution at $55^{\circ} \mathrm{C}$.

Firmness

$1 \% \mathrm{Ca}+\mathrm{SHW}$ treated cucumbers had the highest firmness compared with SHW and $2 \% \mathrm{Ca}+\mathrm{SHW}$ in both seasons. No significant difference was detected between SHW and 2\% $\mathrm{Ca}+\mathrm{SHW}$ in the second season (Fig.6). At the end of cold storage and shelf life at room conditions, firmness of $1 \% \mathrm{Ca}+\mathrm{SHW}$ increased by 8.4 and $4.7 \%$ in the first and second season, respectively, while firmness decreased by 11.6 and $12 \%$ in SHW treated fruits, and 2.6 and $8 \%$ in $2 \%$ $\mathrm{Ca}+\mathrm{SHW}$ treated fruits compared with at harvest time in both seasons, respectively. 


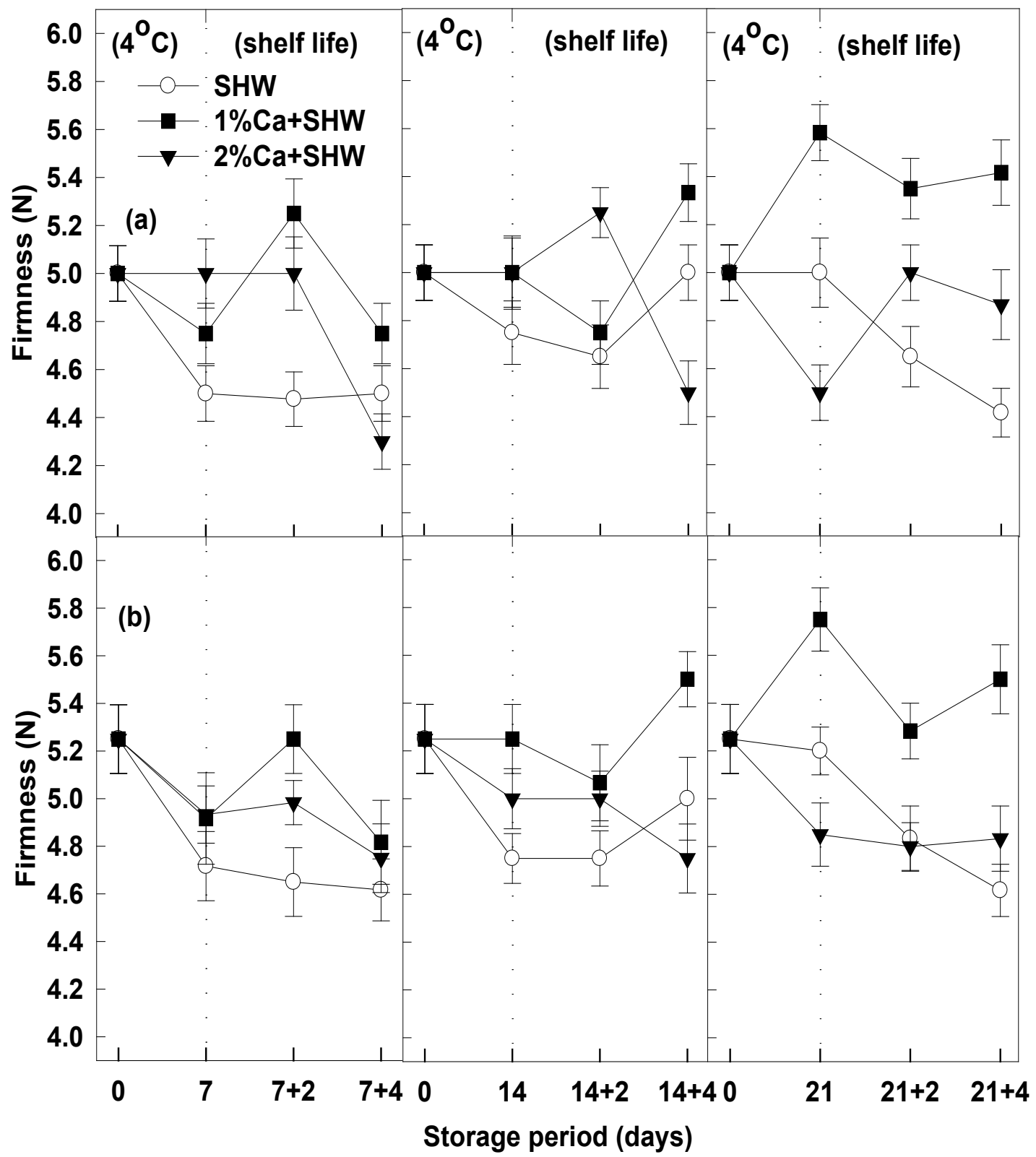

Fig.6. Effect of calcium integrated with hot water treatments on firmness of cucumbers after cold storage at $4^{\circ} \mathrm{C}$ and shelf life at room conditions. a, the first season, $b$, the second season. Values are the mean of $n=3$ and vertical bars indicate the standard error. $\mathrm{SHW}=$ short hot water at $55{ }^{\circ} \mathrm{C}, 1 \% \mathrm{Ca}+\mathrm{SHW}=1 \%$ calcium chloride solution at $55^{\circ} \mathrm{C}, 2 \% \mathrm{Ca}+\mathrm{SHW}=1 \%$ calcium chloride solution at $55{ }^{\circ} \mathrm{C}$.

SSC and sugars

Regarding SSC, no significant differences were observed between the three treatments in both seasons. However, SSC increased after 7 and 14 daysat $4{ }^{\circ} \mathrm{C}$ in the three treatments. $1 \%$ $\mathrm{Ca}+\mathrm{SHW}$ treated fruitshad the highest SSC after 7 days at $4{ }^{\circ} \mathrm{C}$ plus 2 days at room conditions in both seasons and after 14 days at $4{ }^{\circ} \mathrm{C}$ plus 4 days at room conditions in the second season. $2 \% \mathrm{Ca}+\mathrm{SHW}$ treated fruitshad the highest SSC after 21 days of cold storage at $4{ }^{\circ} \mathrm{C}$ and after 2 and 4 days of shelf life at room conditionsin both seasons compared with $1 \% \mathrm{Ca}+\mathrm{SHW}$ and SHW (Fig. 7). 


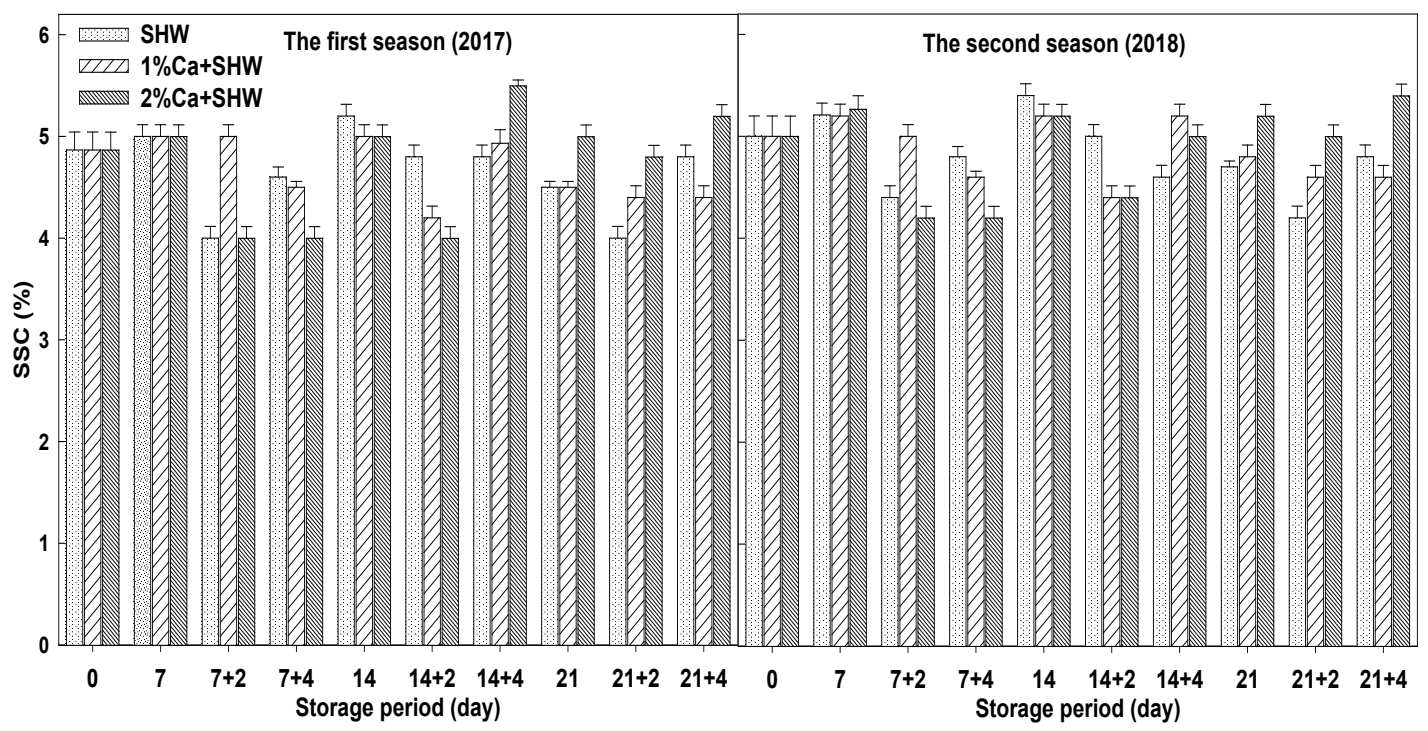

Fig. 7. Effect of calcium integrated with hot water treatments on SSC of cucumbers after cold storage at $4{ }^{\circ} \mathrm{C}$ and shelf life at room conditions. Values are the mean of $n=3$ and vertical bars indicate the standard error. $\mathrm{SHW}=$ short hot water at $55^{\circ} \mathrm{C}, 1 \% \mathrm{Ca}+\mathrm{SHW}=1 \%$ calcium chloride solution at $55{ }^{\circ} \mathrm{C}, 2 \% \mathrm{Ca}+\mathrm{SHW}=1 \%$ calcium chloride solution at $55^{\circ} \mathrm{C}$.

Cucumber fruits of $2 \% \mathrm{Ca}+\mathrm{SHW}$ showed the highest reducing sugarscompared with SHW and $1 \% \mathrm{Ca}+\mathrm{SHW}$. However, no significant difference was observed between SHW and $1 \% \mathrm{Ca}+\mathrm{SHW}$. Reducing sugars increased during the cold storage and shelf life at room conditions. During the initial 7 days of storage at $4{ }^{\circ} \mathrm{C}$, reducing sugars increased in the three treatments then decreased in SHW and $2 \% \mathrm{Ca}+\mathrm{SHW}$ while still high in $1 \%$ $\mathrm{Ca}+\mathrm{SHW}$ after 7 days at $4{ }^{\circ} \mathrm{C}$ plus 2 days at room conditions. SHW had the lowest value after 7 days at $4{ }^{\circ} \mathrm{C}$ plus 2 days at room conditions while $2 \%$ $\mathrm{Ca}+\mathrm{SHW}$ had the highest value followed by $1 \%$ $\mathrm{Ca}+\mathrm{SHW}$. SHW had the highest value after 14 days at $4{ }^{\circ} \mathrm{C}$ plus 2 days at room conditions. At the end of cold storage at $4{ }^{\circ} \mathrm{C}$ and shelf life at room conditions, $2 \% \mathrm{Ca}+\mathrm{SHW}$ had the highest reducing sugars followed by SHW while $1 \% \mathrm{Ca}+\mathrm{SHW}$ had the lowest value (Fig. 8).

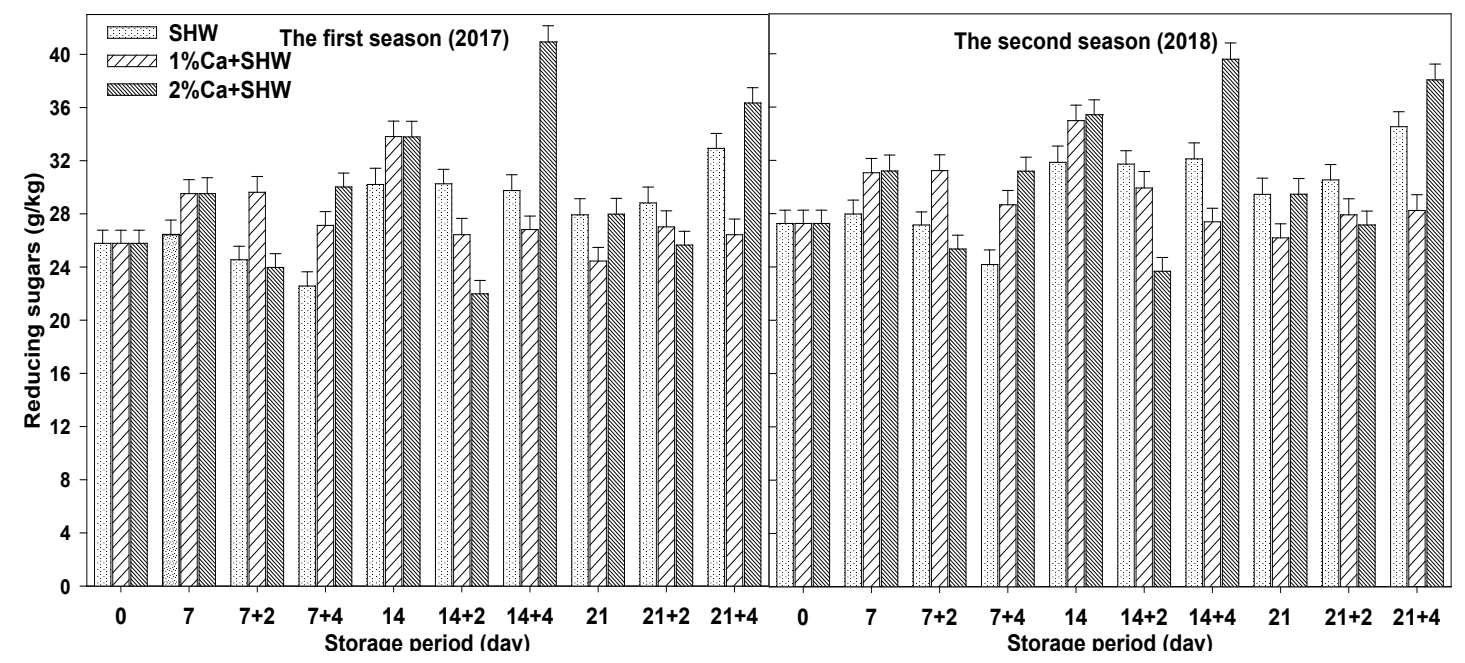

Fig.8. Effect of calcium integrated with hot water treatments on weight loss of cucumbers after cold storage at $4{ }^{\circ} \mathrm{C}$ and shelf life at room conditions. Values are the mean of $n=3$ and vertical bars indicate the standard error. $\mathrm{SHW}=$ short hot water at $55^{\circ} \mathrm{C}, 1 \% \mathrm{Ca}+\mathrm{SHW}=1 \%$ calcium chloride solution at $55{ }^{\circ} \mathrm{C}, 2 \% \mathrm{Ca}+\mathrm{SHW}=1 \%$ calcium chloride solution at $55^{\circ} \mathrm{C}$. 
Concerning non-reducing sugars, $1 \% \mathrm{Ca}+\mathrm{SHW}$ had the highest non-reducing sugars compared with SHW and $2 \% \mathrm{Ca}+\mathrm{SHW}$ treatments. However, no significant difference was observed between SHW and $1 \% \mathrm{Ca}+\mathrm{SHW}$ in the first season.During the storage periods, non-reducing sugars decreased sharply in the three treatments. During 14 days at $4{ }^{\circ} \mathrm{C}$ plus 4 days at room conditions, $1 \% \mathrm{Ca}+\mathrm{SHW}$ had the highest non-reducing sugars except at 2 days at room conditions after 7 days at $4{ }^{\circ} \mathrm{C}$. $2 \%$
$\mathrm{Ca}+\mathrm{SHW}$ had the highest value followed by SHW in the first season and $1 \% \mathrm{Ca}+\mathrm{SHW}$ in the second season after 21 days at $4{ }^{\circ} \mathrm{C}$, then declined in the three treatments after 21 days of cold storage plus 2 daysat room conditions. However, SHW had the highest non-reducing sugars followed by $2 \% \mathrm{Ca}+\mathrm{SHW}$ while $1 \% \mathrm{Ca}+\mathrm{SHW}$ had the lowest value when shelf life was extended to 4 days at room conditions after 21 days of cold storage at $4^{\circ} \mathrm{C}$ (Fig. 9).

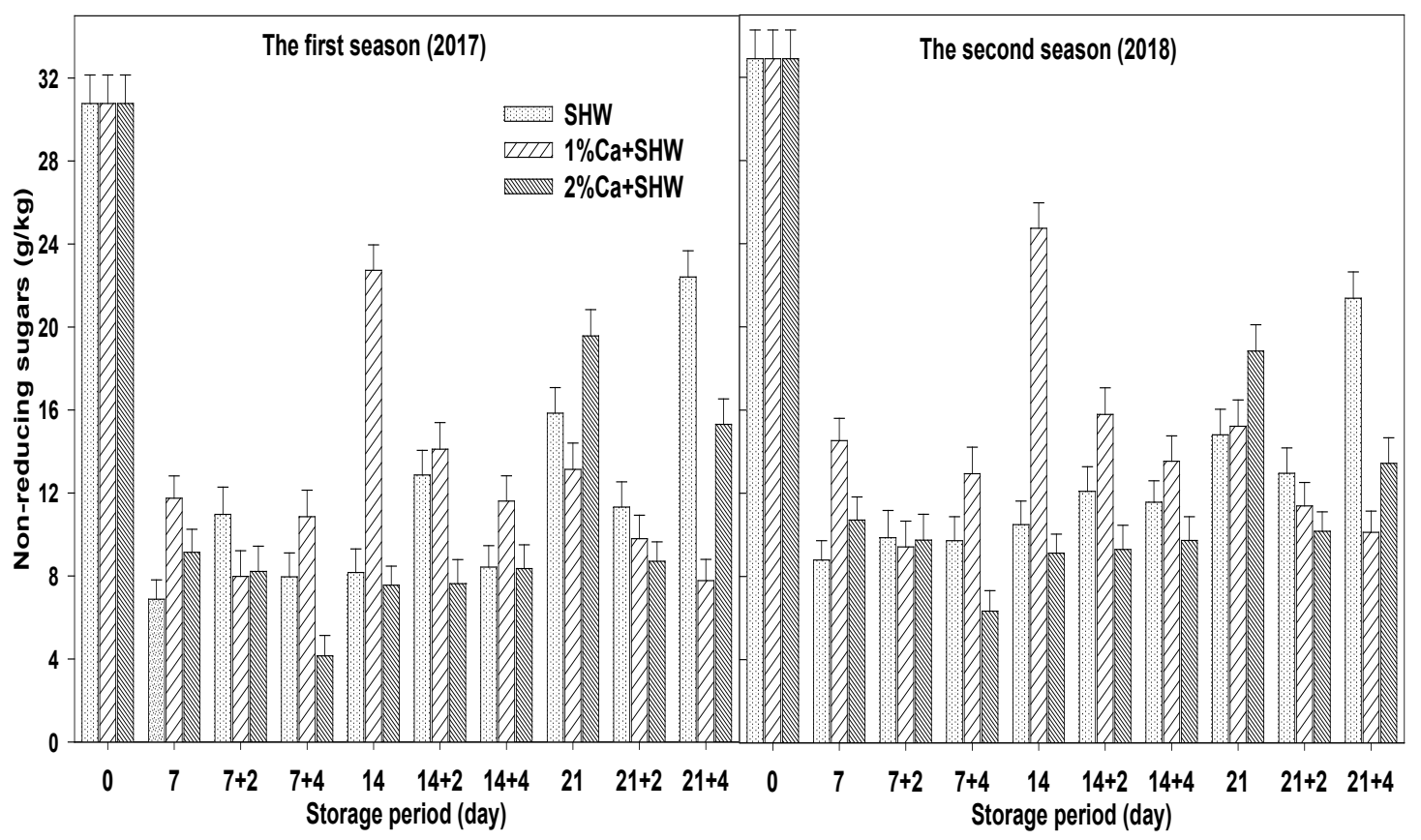

Fig. 9. Effect of calcium integrated with hot water treatments on non-reducing sugars of cucumber after cold storage at $4^{\circ} \mathrm{C}$ and shelf life at room conditions. Values are the mean of $n=3$ and vertical bars indicate the standard error. SHW $=$ short hot water at $55{ }^{\circ} \mathrm{C}, 1 \% \mathrm{Ca}+\mathrm{SHW}=1 \%$ calcium chloride solution at $55^{\circ} \mathrm{C}, 2 \%$ $\mathrm{Ca}+\mathrm{SHW}=1 \%$ calcium chloride solution at $55^{\circ} \mathrm{C}$.

\section{Total phenolics}

Total phenolics increased in $1 \% \mathrm{Ca}+\mathrm{SHW}$ treated fruits while decreased in SHW and $2 \%$ $\mathrm{Ca}+\mathrm{SHW}$ after the initial seven days of cold storage at $4{ }^{\circ} \mathrm{Ccompared}$ to at harvest time in both seasons, then increased in the three treatments after 14 days at $4{ }^{\circ} \mathrm{C}$, however, $1 \% \mathrm{Ca}+\mathrm{SHW}$ had the highest value (Fig. 10). SHW had the lowest value after the end of shelf life (4 days at room conditions) after cold storage periods except at 4 daysat room conditions after 21 days at $4{ }^{\circ} \mathrm{C}$ in the second seasons, while $2 \% \mathrm{Ca}+\mathrm{SHW}$ had the highest value after the end of shelf lifeat room conditionsin both seasons. $1 \% \mathrm{Ca}+\mathrm{SHW}$ had the highest value at the first shelf life period after 7,14 and 21 days of cold storage at $4{ }^{\circ} \mathrm{C}$ in both seasons except at 2 daysat room conditions after 21 days at $4{ }^{\circ} \mathrm{C}$ in the first season. 


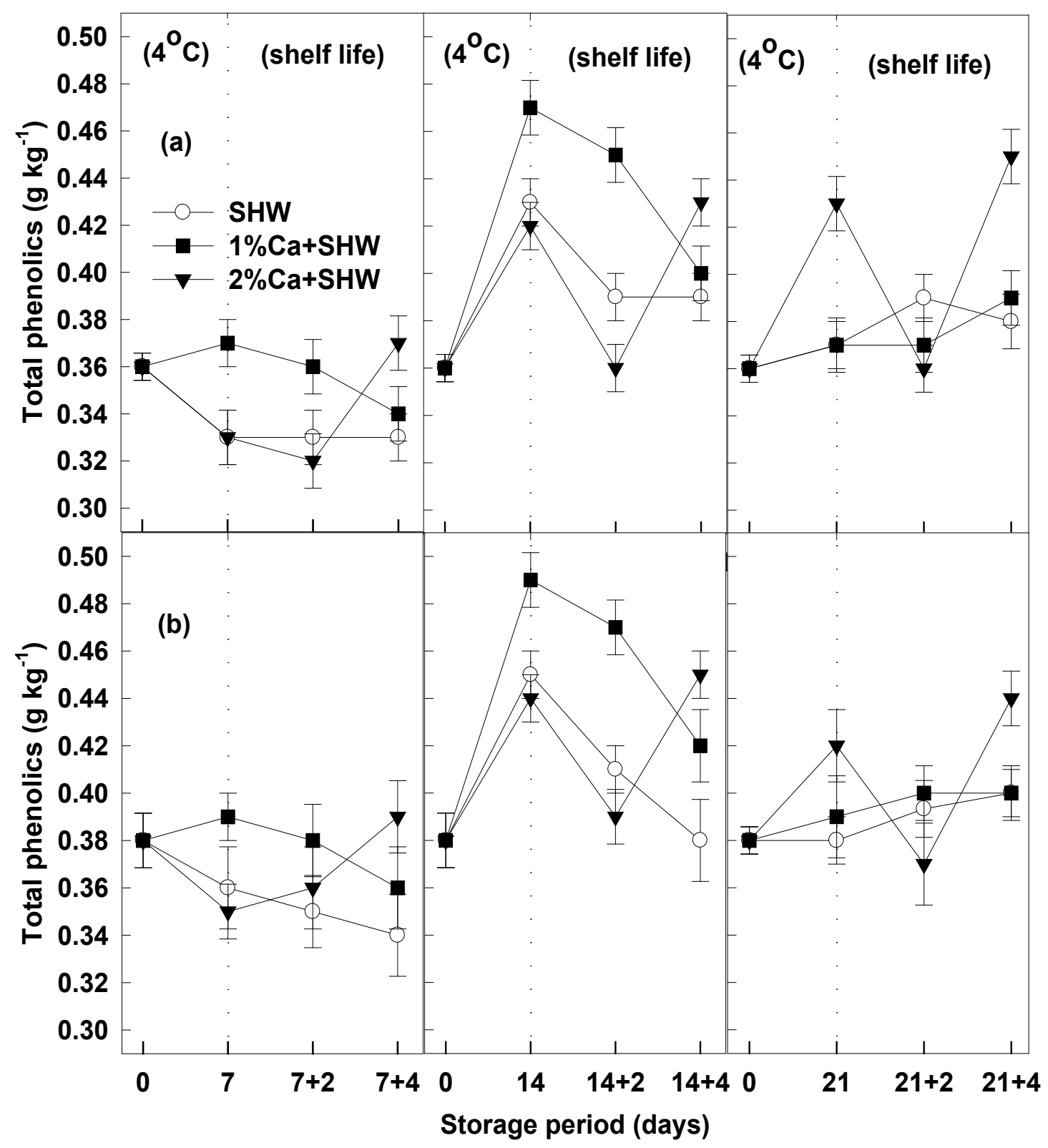

Fig. 10. Effect of calcium integrated with hot water treatments on total phenolics of cucumbers after cold storage at $4^{\circ} \mathrm{C}$ and shelf life at room conditions. a, the first season, $b$, the second season. Values are the mean of $n=3$ and vertical bars indicate the standard error.SHW= short hot water at $55^{\circ} \mathrm{C}, 1 \% \mathrm{Ca}+\mathrm{SHW}=1 \%$ calcium chloride solution at $55{ }^{\circ} \mathrm{C}, 2 \% \mathrm{Ca}+\mathrm{SHW}=1 \%$ calcium chloride solution at $55{ }^{\circ} \mathrm{C}$.

Electrolyte leakage

Generally, a sharp increasing was detected in all treatments after the first week of storage at $4{ }^{\circ} \mathrm{C}$, and then decreased after ward (Fig. 11). During the cold storage and shelf life at room conditions, $1 \% \mathrm{Ca}+\mathrm{SHW}$ showed the lowest electrolyte leakage in both season except at 4 days at room conditions after 14 days at $4{ }^{\circ} \mathrm{C}$ in the first season. At the end of storage, $2 \% \mathrm{Ca}+\mathrm{SHW}$ had the highest value followed by SHW while $1 \%$ $\mathrm{Ca}+\mathrm{SHW}$ had the lowest value in both seasons. 


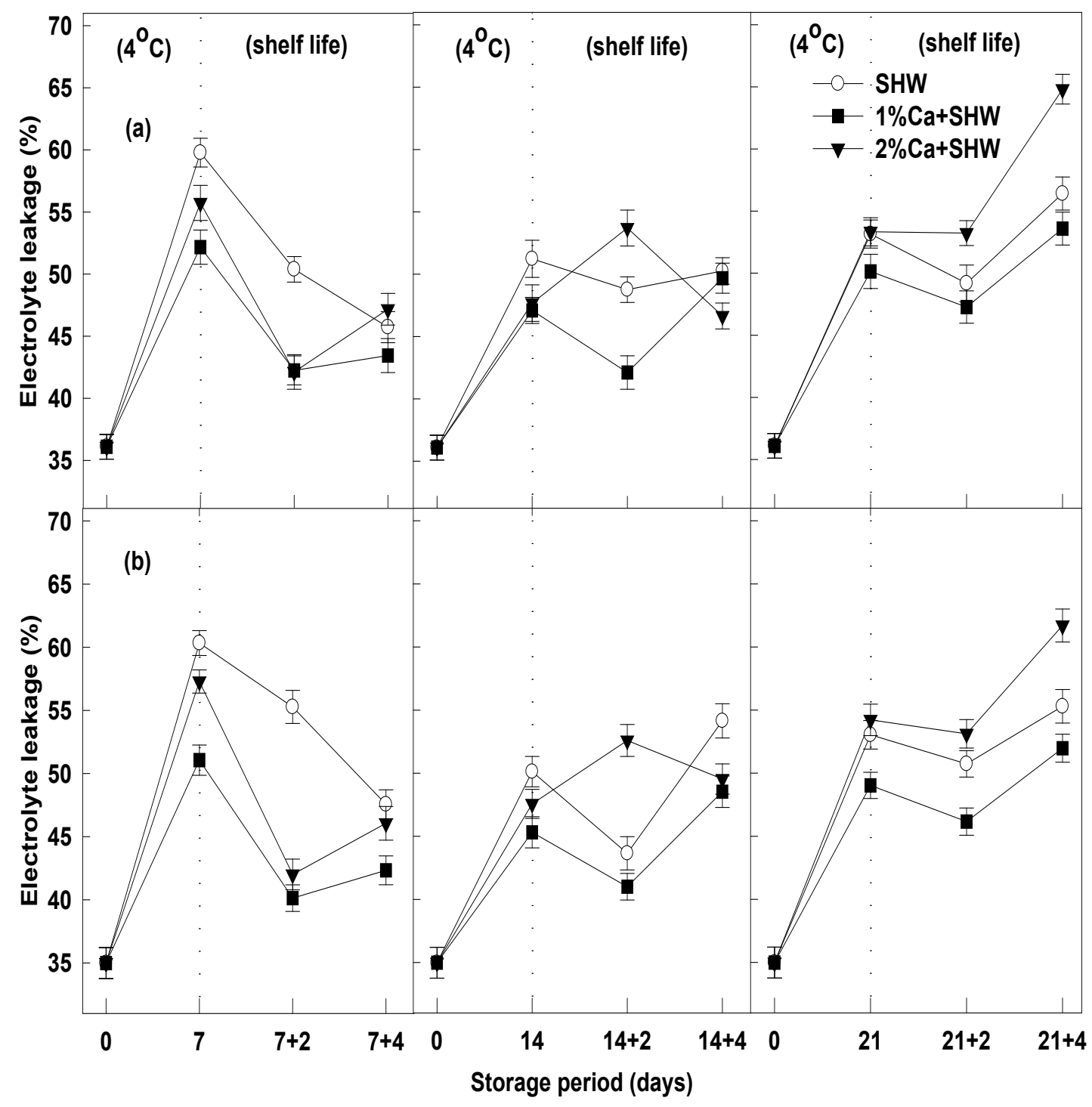

Fig. 11. Effect of calcium integrated with hot water treatments on electrolyte leakage of cucumbers after cold storage at $4{ }^{\circ} \mathrm{C}$ and shelf life at room conditions. a, the first season, b, the second season. Values are the mean of $\mathrm{n}=3$ and vertical bars indicate the standard error. $\mathrm{SHW}=$ short hot water at $55^{\circ} \mathrm{C}, 1 \% \mathrm{Ca}+\mathrm{SHW}=$ $1 \%$ calcium chloride solution at $55{ }^{\circ} \mathrm{C}, 2 \% \mathrm{Ca}+\mathrm{SHW}=1 \%$ calcium chloride solution at $55^{\circ} \mathrm{C}$.

Peroxidase activity

The peroxidase activity increased with prolongation of cold storage time at $4^{\circ} \mathrm{C}$ and shelf life at room conditions (Fig. 12). The highest activity was recorded at room conditions. SHW had the highest activity during 21 days at $4{ }^{\circ} \mathrm{C}$ plus 2 days at room conditions in both seasons except at 7 days at $4{ }^{\circ} \mathrm{C}$ in the first season while $2 \% \mathrm{Ca}+\mathrm{SHW}$ had the lowest activity during 21 days at $4{ }^{\circ} \mathrm{C}$ plus 2 days at room conditions in both seasons except at 7 days at $4{ }^{\circ} \mathrm{C}$, and 14 days at $4{ }^{\circ} \mathrm{C}$ plus 2 days at room conditions in the first season. However, at the end of storage, $2 \% \mathrm{Ca}+\mathrm{SHW}$ had the highest activity (116.50 and $112.61 \mathrm{U} \mathrm{kg}^{-1} \mathrm{~s}^{-1}$ ) followed by SHW (111.94 and $\left.105.72 \mathrm{U} \mathrm{kg}^{-1} \mathrm{~s}^{-1}\right)$ while $1 \% \mathrm{Ca}+\mathrm{SHW}$ had the lowest activity $\left(55.83\right.$ and $\left.52.11 \mathrm{U} \mathrm{kg}^{-1} \mathrm{~s}^{-1}\right)$ in both seasons, respectively. 


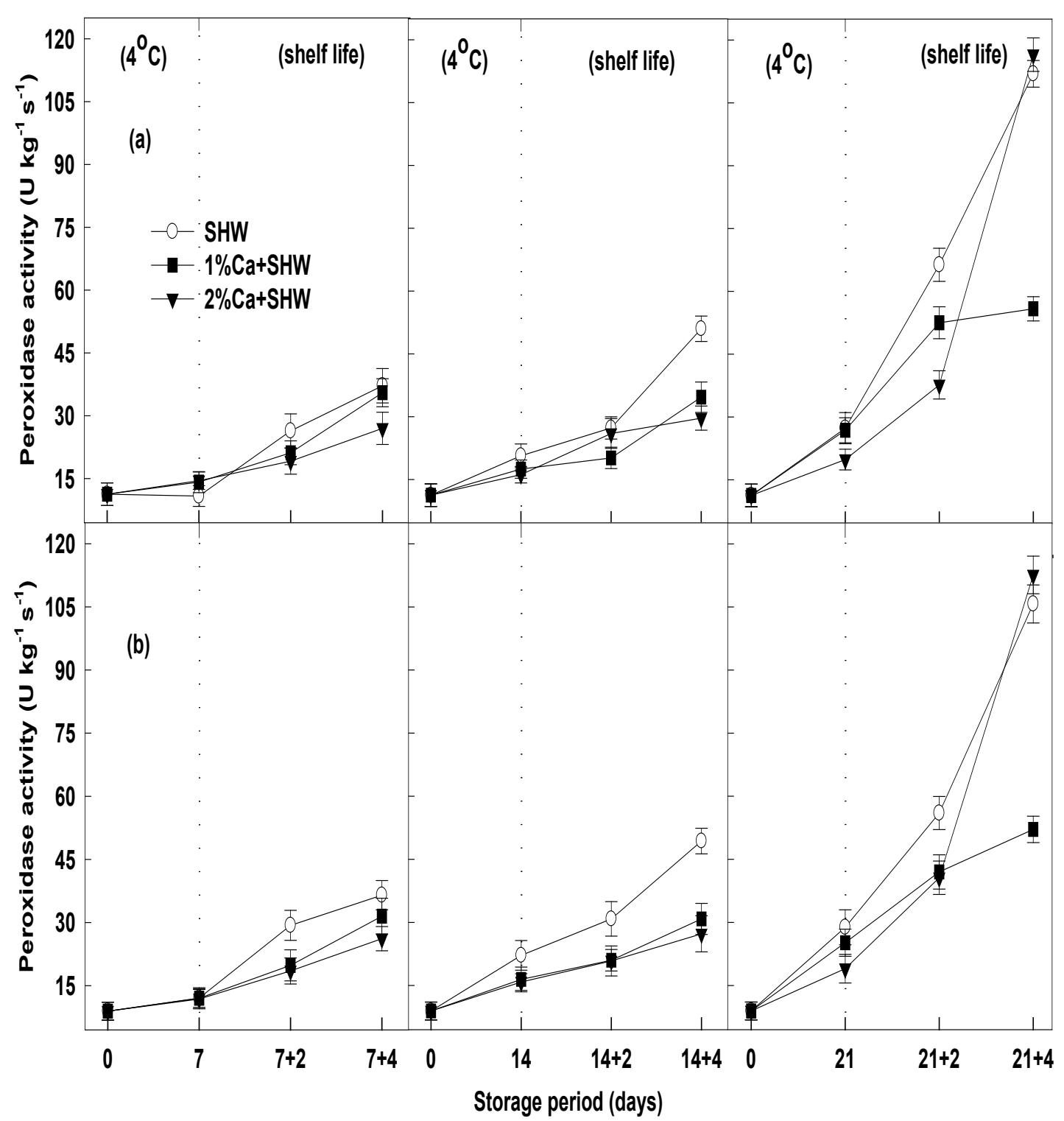

Fig. 12. Effect of calcium integrated with hot water treatments on peroxidase activity of cucumbers after cold storage at $4{ }^{\circ} \mathrm{C}$ and shelf life at room conditions. a, the first season, $\mathrm{b}$, the second season. Values are the mean of $\mathrm{n}=3$ and vertical bars indicate the standard error. $\mathrm{SHW}=$ short hot water at $55^{\circ} \mathrm{C}, 1 \% \mathrm{Ca}+\mathrm{SHW}=$ $1 \%$ calcium chloride solution at $55{ }^{\circ} \mathrm{C}, 2 \% \mathrm{Ca}+\mathrm{SHW}=1 \%$ calcium chloride solution at $55^{\circ} \mathrm{C}$.

Catalase activity

Catalase activity in $1 \% \mathrm{Ca}+\mathrm{SHW}$ treated cucumbers was higher than that of SHW and $2 \%$ $\mathrm{Ca}+\mathrm{SHW}$ duringthe two weeks of storage at $4{ }^{\circ} \mathrm{C}$ plus 2 days of shelf life at room conditions in both seasons, then decreased after 14 days at $4{ }^{\circ} \mathrm{C}$ plus 4 days at room conditions. The activity of catalase increased sharply by the three treatments after
21 days of cold storage, and was still high after 21 days at $4{ }^{\circ} \mathrm{C}$ plus 2 days of shelf life at room conditions. $2 \% \mathrm{Ca}+\mathrm{SHW}$ had the highest activity (792.56 and $827.72 \mathrm{U} \mathrm{kg}^{-1} \mathrm{~s}^{-1}$ ) in both seasons, respectively,followed by SHW $\left(747.56 \mathrm{U} \mathrm{kg}^{-1} \mathrm{~s}^{-1}\right)$ in the first season and $1 \% \mathrm{Ca}+\mathrm{SHW}\left(749.17 \mathrm{U} \mathrm{kg}^{-1}\right.$ $\mathrm{s}^{-1}$ ) in the second season at the end of the storage (Fig.13). 


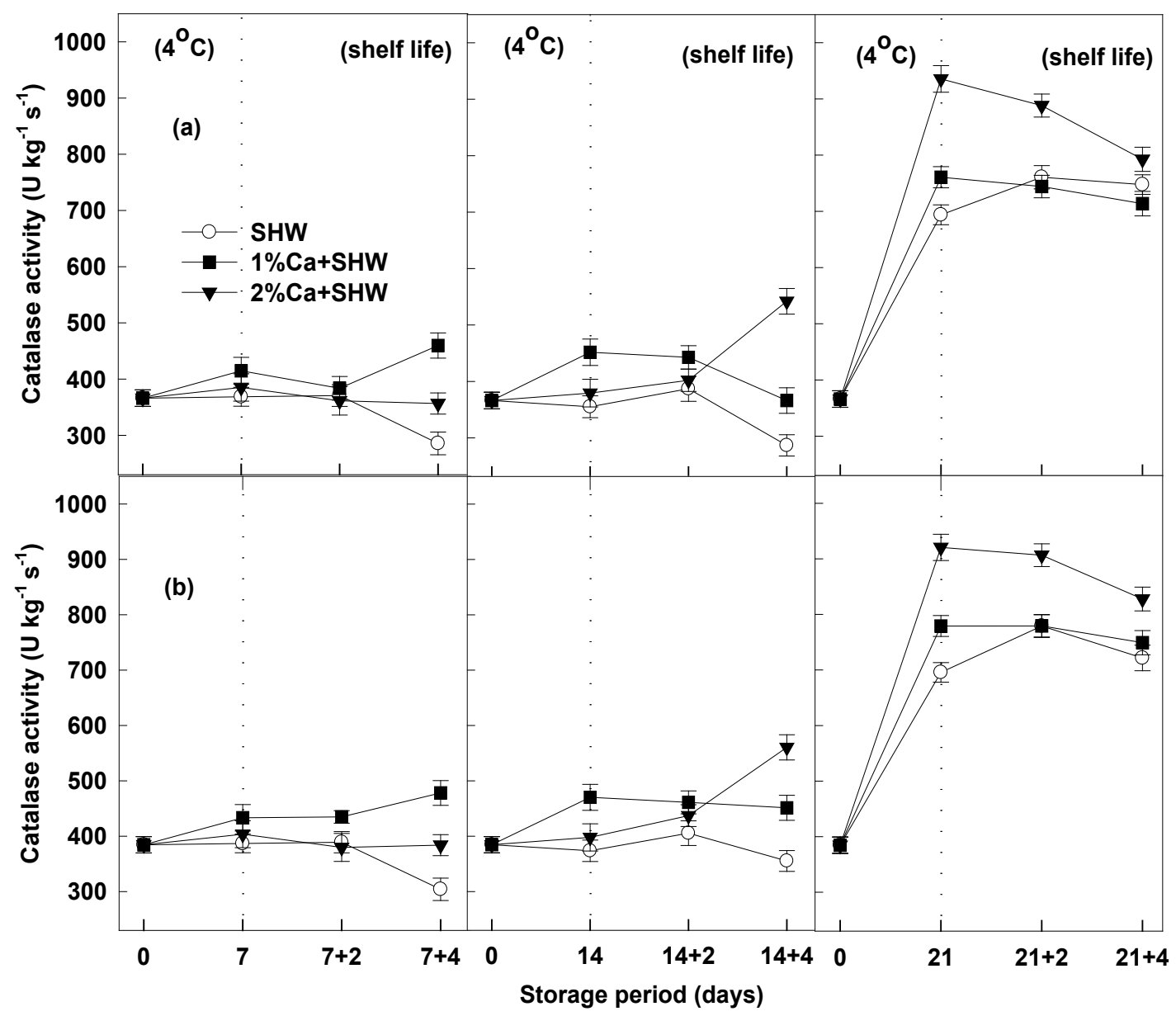

Fig. 13. Effect of calcium integrated with hot water treatments on catalase activity of cucumbers after cold storage at $4{ }^{\circ} \mathrm{C}$ and shelf life at room conditions. a, the first season, $b$, the second season. Values are the mean of $\mathrm{n}=3$ and vertical bars indicate the standard error. $\mathrm{SHW}=$ short hot water at $55^{\circ} \mathrm{C}, 1 \% \mathrm{Ca}+\mathrm{SHW}=1 \%$ calcium chloride solution at $55^{\circ} \mathrm{C}, 2 \% \mathrm{Ca}+\mathrm{SHW}=1 \%$ calcium chloride solution at $55{ }^{\circ} \mathrm{C}$.

\section{Discussion}

Calcium chloride is an eco-safe compound and was plenty used in maintaining quality of vegetables. The combination of $\mathrm{CaCl}_{2}$ and short hot water resulted in a synergistic effect on alleviating chilling injury, inducing antioxidant enzymes and quality assurance of cucumbers compared with short hot water alone. Moisture content of vegetables is an importantfactorfor its quality and storage for a longer period. Weight loss is due to transpiration, respiration and metabolic activity. $1 \% \mathrm{Ca}+\mathrm{SHW}$ treated cucumbers had less weight loss than SHW and 2\% Ca+SHW. Calcium chloride integrates with cell wall and works as a semipermeable membrane, which reduces the respiration rate in fruits and evapo-transpiration due to the alteration ofmembrane permeability and decrease endogenous substrate catabolism (Lata et al., 2018), while short hot water dipping at $55{ }^{\circ} \mathrm{C}$ for $5 \mathrm{~min}$ improves epicuticular wax and cuticle of cucumber fruits (Nasef, 2018). This indicates that combining $1 \% \mathrm{CaCl}_{2}$ and short hot water at $55{ }^{\circ} \mathrm{C}(1 \% \mathrm{Ca}+\mathrm{SHW})$ is an effective treatment to reduce weight loss of cucumbers during cold storage at $4{ }^{\circ} \mathrm{C}$ and shelf life at room conditions.

Many researchers have recorded good results in improving or maintaining appearance when a combination of calcium dipping is used (Aguayo et al., 2008, Silveira et al., 2011 and Aguayo et al., 2015). Appearance was strongly maintained by SHW or $1 \% \mathrm{Ca}+\mathrm{SHW}$. However, the best treatment was $1 \% \mathrm{Ca}+\mathrm{SHW}$ (the combination of $1 \%$ calcium chloride with short hot water). $2 \%$ 
$\mathrm{Ca}+\mathrm{SHW}$ had the lowest appearance compared with SHW or $1 \% \mathrm{Ca}+\mathrm{SHW}$. Maintenance of appearance in $1 \% \mathrm{Ca}+\mathrm{SHW}$ treated cucumbers may be due to reduce the weight loss and maintain the color.No decay was detected in the three treatments (data not shown). Short hot water alone or combined with 1 or $2 \%$ calcium chloride enhanced resistance of tissue to fungal attack through stabilizing cell walls, thus makes them more resistance to harmful enzymes which were produced by fungi (Conway \& Sams, 1984, Conway et al., 1994 and Nasef, 2018).

The combination of calcium chloride and hot water maintained papaya hue angle (Ayón-Reyna et al., 2017). In consistent with this report, $1 \%$ $\mathrm{Ca}+\mathrm{SHW}$ treated cucumbers had the better color followed by SHWwhile $2 \% \mathrm{Ca}+\mathrm{SHW}$ had the worst color. This result suggests that $1 \% \mathrm{Ca}+\mathrm{SHW}$ delays the ripening process (Ayón-Reyna et al., 2017), and reducing chlorophyll degradation (Lata et al., 2018).

$1 \% \mathrm{Ca}+\mathrm{SHW}$ treated cucumbers had moderately full taste while SHW had moderate taste at the end of the storage. $2 \% \mathrm{Ca}+\mathrm{SHW}$ imparted a slight salty taste to cucumber surface but was not rejected by panelists. The results illustrated that the combination of $1 \%$ calcium chloride and short hot water at $55{ }^{\circ} \mathrm{C}(1 \%$ $\mathrm{Ca}+\mathrm{SHW})$ was more effective in preserving cucumber tastethan short hot water treatment alone, as reported by Moradinezhad and Khayyat (2014). The preservation of cucumber taste by $1 \% \mathrm{Ca}+\mathrm{SHW}$ may be due to theenhancement inquality retention.

Susceptibility of cucumbers to chilling injury during the cold storage can lead to loss market value and quality. Calcium ions stabilize proteins to denaturants at low temperature, presumably by forming links in the proteins and reducing their hydration (Minorsky, 1985). Calcium chloride in combination with heat treatment alleviates chilling injury in sapota (Jitthum et al., 2002), and pomegranate (Moradinezhad and Khayyat, 2014). $2 \% \mathrm{Ca}+\mathrm{SHW}$ was the worst treatment while $1 \% \mathrm{Ca}+\mathrm{SHW}$ was the best treatment in mitigating chilling injury in cucumbers during the cold storage and shelf life at room conditions. These results indicate that $1 \% \mathrm{Ca}+\mathrm{SHW}$ was more effective in enhancing chilling tolerance and reducing chilling injury symptoms than short hot water alone (SHW) and $2 \% \mathrm{Ca}+\mathrm{SHW}$. Integration of short hot water and $1 \%$ calcium chloride probably maintained the tissue integrity, and hence $1 \% \mathrm{Ca}+\mathrm{SHW}$ treated cucumber tissues had resistance to chilling injury.

The beneficial effects of calcium dipping in improving firmness of strawberries probably attribute to reduce the breakdown of chelatesoluble pectin and sodium carbonate-soluble pectin chains via strengthening the ionic crosslinks between these pectin molecules in the cell wall (Chen et al., 2011). Calcium uptake is affected by temperature, high temperature $\left(50-60^{\circ} \mathrm{C}\right)$ combined with calcium chloride dipping which results in increasing diffusion of calcium into the tissue, during apoplast poresand enhancing tissue calcium fixation (Silveira et al., 2011). The application of hot water containing calcium chloride significantly reduced the softening of kiwifruit (Shahkoomahally and Ramezanian, 2015), and fresh-cut melon (Aguayo et al. 2008). The combination of $1 \%$ calcium chloride and short hot water $(1 \% \mathrm{Ca}+\mathrm{SHW})$ resulted ina synergistic improvement in cucumber firmness. This satisfactory result of $1 \% \mathrm{Ca}+\mathrm{SHW}$ in maintaining cucumber firmness may be due to improve cell wall and membrane integrity, increase cell-cell adhesion and cohesion, and cell turgor. Likewise, cell wall degradation enzymes may be disrupted by the combination of $1 \%$ calcium chloride and short hot water.SSC increased in all treatments at the first and secondperiods of the cold storage at $4^{\circ} \mathrm{C}$, which can be explained by the increasing reducing sugars in cucumber at the same times, indicating the carbohydrates solublization and synthesis, as found by Liu et al. (2009). The three treatments had not significant differences in both seasons, and this result agrees with the report of Rabiei et al. (2011a). The highest SSC was documented in $2 \% \mathrm{Ca}+\mathrm{SHW}$ treated cucumbers followed by SHW while the lowest was noticed in $1 \% \mathrm{Ca}+\mathrm{SHW}$ at the end storage period. These observations coincide with the trend of reducing sugars at the same time. However, $1 \% \mathrm{Ca}+\mathrm{SHW}$ exhibited the best quality during the cold storage periods and shelf life at room conditions.Consistently, SSC was lower in calcium treatment than the control in papaya (Lata et al., 2018), and apple (Hemmaty et al., 2007 and Ayón-Reyna et al., 2017), and sweet pepper (Rao et al., 2011). In contrast, SSC was higher in $1 \%$ calcium treatment than $3 \%$ calcium or controlat the end of storage of apricot (Liu et al., 2009), and this variation may attribute to the concentration of calcium and plant species.

Changes in soluble sugars during vegetables storage are due to the equilibrium between

Egypt. J. Hort. Vol. 46, No.1 (2019) 
catabolic and anabolic processes. In this study, an increase in reducing sugars was noted after 7 days at $4{ }^{\circ} \mathrm{C}$, and this corresponded to a sharp decrease in non-reducing sugars at the same time in the three treatments. This may be clarified by the hydrolysis of sucrose to reducing sugars (Aguayo et al. 2008). The highest reducing sugars were observed in $2 \% \mathrm{Ca}+\mathrm{SHW}$ treated cucumbers. However, the lowest reducing and non-reducing sugars were recorded in $1 \% \mathrm{Ca}+\mathrm{SHW}$ at the end of storage period. This may suggest that $1 \%$ $\mathrm{Ca}+\mathrm{SHW}$ resulted inreducing the conversion of carbohydrates to soluble sugars (Pila et al., 2010), by retarding the fruit ripening and senescence (Ferguson 1984 and Silveira et al., 2011), via the reduction of respiration (Rahman et al., 2016). It might be due to the inhibition of hydrolysis enzymes which convert starch to sugars (Gupta et al., 2011).

Phenolic compounds in vegetables and fruitprotect cells from oxidative injury. The high level of phenolicsindicatestheinduction of defense mechanism (Chawla et al., 2018), andthe maintenance of cellular integrity (Shahkoomahally and Ramezanian, 2015). Impregnation of cucumbers in short hot water containing $1 \%$ calcium chloride resulted in increasing total phenolics after 7 and 14 days of cold storage plus 2 days of shelf life at room conditions, then decreased but not less than at harvest. This suggests that the combination of $1 \%$ calcium chloride and short hot water is more effective in preserving quality of cucumbers. Aguayo et al. (2015) found that all phenolic compounds in apple did not show the same response to the combination of hot water and calcium treatment, and postulated that it may attribute to variances in the different phenolic compounds metabolism. In the future, the individual phenolicsin cucumbers need to study to determine which of them increase and which decrease during the cold storage and shelf life.

Electrolyte leakage is used to estimate thecell membrane integrity and considered as an indicator for membranedamage and chilling injury. The increase in electrolyte leakage should be expected when the fruit are exposed to stress conditions as low temperatures or at the end of fruit ripening (Bagheri et al., 2015). Calcium is an efficient factor in reducing ion leakage, loss of phospholipids and protein, consequently maintaining the membrane integrity (Lester and Grusak, 1999). In this study, the combined treatment of $1 \%$ calcium chloride and short hot water had the lowest electrolyte leakage compared with $2 \%$ calcium chloride in combination with short hot water treatment and short hot water alone. This suggests that $1 \%$ calcium chloride and short hot water is more effective in decreasing electrolyte leakage and alleviating chilling injury by protecting cell membrane.

Plant peroxidases localize mainly in vacuoles and cell walls (Penel et al., 1999). Peroxidases are consideredubiquitous enzymes which play diverse functions in the life cycle of plant such as metabolism of cell wall, lignification, suberization, wound healing, reactive oxygen species metabolism, growth and repining of fruit, seed germination, defense against pathogens and tissue damage (Pandey et al., 2017). The increase in peroxidase activity indicates that tissues exposed to stress and damage while the low peroxidase activity may reveal that these tissues have less damage and chilling injury, as found by Nasef (2018). Calcium ion was necessary to induce the cross-linking of polygalacturonan chains into a structure which can be recognized by the isoperoxidases (Penel et al., 1999). The results of investigations about the effects of calcium on peroxidase activity are inconsistent, with some showing increased activity (Sams\& Conway, 1993 and Rao et al., 2011), while decreases have been recorded by others (Lamikanra and Watson, 2007, Safizadeh et al., 2007 and Wu et al., 2015), and this may attribute to the difference concentrations of calcium(Lima et al., 2000), and the high isoforms number which allow a fine balance between functions of antagonistic peroxidase such as cell wall loosening and crosslinking, and the variation between species in isoforms could explain the several discrepancies among reports on the different peroxidases regulation for physiological processes (Passardi et al., 2005). In this study, peroxidase activity increased graduallyin the three treatments but was higher in short hot water aloneand was lower in $2 \%$ calcium chloride in combination with short hot water followed by $1 \% \mathrm{Ca}+\mathrm{SHW}$ after 21 days at $4^{\circ} \mathrm{C}$ plus 2 days at room conditions. However, $1 \%$ $\mathrm{Ca}+\mathrm{SHW}$ exhibited the lowest peroxidase activity at the end of storage. These results suggest that $1 \% \mathrm{Ca}+\mathrm{SHW}$ was more effective in preventing tissues damage, reducing electrolyte leakage, inducing chilling tolerance, thus maintaining the quality of cucumbers under low temperature stress and shelf life at room conditions. 
Cold stress induces injury in plant by toxic oxygen forms (Sala and Lafuente, 2000). Catalase is an essentialoxyradical detoxification enzyme in tissues of plant (Xing et al., 2011), and plays a vital role in inducing chilling tolerance and protects the cells from damage (Sala \& Lafuente, 1999 and Nasef, 2018), and retards the ripening and senescence of fruit by removing the excess of hydrogen peroxide from the tissues (Rabiei et al., 2011b). Catalase activity increased in calcium chloride treated fruit compared with untreated (Safizadeh et al., 2007, Rabiei et al., 2011a, Shirzadeh et al., 2011, Kou et al., 2014 and Bagheri et al., 2015). In the present investigation, $1 \%$ calcium chloride in combination with short hot water treatment induced catalase activity. This could suggest that $1 \% \mathrm{Ca}+\mathrm{SHW}$ reduces electrolyte leakage and chilling injury, prevents cell damage and delays the ripening and senescence of fruit,thusquality assurance of cucumbers under cold stress and shelf lifeat room conditions by stimulating catalase activity.

In general, the slight variations between the two seasons in all parameters may attribute to the agricultural practices and climate changes during the cucumber growth season but it did notaffecton the results.

\section{Conclusion}

The current studyrevealed that $1 \%$ calcium chloride in combination with short hot water had the lowest weight loss and chilling injury. Additionally, the best appearance and taste and the highest firmness were in $1 \% \mathrm{Ca}+\mathrm{SHW}$ treated cucumbers. Application of $1 \% \mathrm{Ca}+\mathrm{SHW}$ kept color and sugars of cucumbers. Also, $1 \% \mathrm{Ca}+\mathrm{SHW}$ was more effective in reducing electrolyte leakage, keeping total phenolics, inhibiting peroxidase activity, inducingcatalase activity. These results exhibited the effectiveness of $1 \% \mathrm{Ca}+\mathrm{SHW}$ treatment on cucumber quality in both seasons. Therefore, $1 \%$ calcium chloride in combination with short hot water treatment can be applied by farmers and traders to maintain quality of cucumbers during cold storage at $4^{\circ} \mathrm{C}$ and shelf life at room conditions.

\section{Acknowledgment}

The author is grateful to his parents, his wife and Horticulture Department, Faculty of Agriculture, Suez Canal University for their encouragement and help throughout this study.

\section{Funding statements}

The author would like to extend his appreciation to the Horticulture Department, Faculty of Agriculture, Suez Canal University for supplying the chemicals for this research work.

\section{Conflicts of interest}

The author declares that he has no conflicts of interest related to the publication of this study.

\section{References}

Aguayo, E., Requejo-Jackman, C., Stanley, R. and Woolf, A. (2015) Hot water treatment in combination with calcium ascorbate dips increases bioactive compounds and helps to maintain fresh-cut apple quality. Postharvest Biol. Technol., 110, 158-165.

Aguayo, E., Escalona, V.H. and Artés, F. (2008) Effect of hot water treatment and various calcium salts on quality of fresh-cut 'Amarillo' melon. Postharvest Biol. Technol.,47, 397-406.

Ayón-Reyna, L.E., López-Valenzuela, J.Á., Delgado-Vargas, F., López-López, M.E., Molina-Corral, F.J., Carrillo-López, A. and Vega-García, M.O. (2017) Effect of the combinationhotwater-calciumchlorideonthein vitro growth of Colletotrichumgloeosporioides and the postharvest quality of infected papaya. Plant Pathol. J., 33, 572-581.

Bagheri, M., Esna-Ashari, M. and Ershadi, A. (2015) Effect of postharvest calcium chloride treatment on the storage life and quality of persimmon fruits (Diospyros kakiThunb.) cv. Karaj. Int. J. Hort. Sci. Technol., 2, 15-26.

Chawla, S., Devi, R. and Jain, V. (2018) Changes in physicochemical characteristics of guava fruits due to chitosan and calcium chloride treatments during storage. J. Pharmacogn. Phytochem., 7, 1035-1044.

Chen, F., Liu, H., Yang, H., Lai, S., Cheng, X., Xin, Y., Yang, B., Hou, H., Yao, Y., Zhang, S., $\mathrm{Bu}, \mathrm{G}$. and Deng, Y. (2011) Quality attributes and cell wall properties of strawberries (Fragariaannanassa Duch.) under calcium chloride treatment. Food Chemistry, 126, 450459.

Conway, W. S., Sams, C.E., Wang, C.Y. and Abbott, J. A. (1994) Additive effects of postharvest calcium and heat treatment on reducing decay and maintaining quality in apples. J. Amer. Soc. Hort. Sci., 119, 49-53.

Egypt. J. Hort. Vol. 46, No.1 (2019) 
Conway, W.S. and Sams. C.E. (1984) Possible mechanisms by which postharvest calcium treatment reduces decay in apples. Phytopathology, 74, 208-210.

Dubois, M.K.A., Hamilton, J.K., Rebers, P.A. and Smith, F. (1956) Colorimetric method for determination of sugars and related substances. Anal. Chem., 28, 350-356.

Elwan, M.W.M., Nasef, I.N., El Seifi, S.K., Hassan, M.A. and Ibrahim, R.E. (2015) Storability, shelf-life and quality assurance of sugar snap peas (cv. Super sugar snap) using modified atmosphere packaging.Postharvest Biol. Technol., 100, 205-211.

Ferguson, I.B. (1984) Calcium in plant senescence and fruit ripening. Plant Cell Environ., 7, 477-489.

Goth, L. (1991)A simple method for determination of serum catalase activity and revision of reference range.Clinics ChimicaActa, 196, 143-152.

Gupta, N., Jawandha S.K. and Gill, P.S. (2011) Effect of calcium on cold storage and poststorage quality of peach. J. Food Sci. Technol., 48, 225-229.

Hakim, A., Purvis, A.C. and Mullinix, B.G. (1999) Differences in chilling sensitivity of cucumber varieties depends on storage temperature and the physiological dysfunction evaluated. Postharv. Biol. Technol., 17, 97-104.

Hemmaty, S., Moallemi, N. and Naseri, L. (2007) Effect of UV-C radiation and hot water on the calcium content and postharvest quality of apples.Spanish J. Agric. Res., 5, 559-568.

Huan, C., Han, S., Jiang, L., An, X., Yu, M., Xu, Y., Ma, R. and Yu, Z. (2017) Postharvest hot air and hot water treatments affect the antioxidant system in peach fruit during refrigerated storage.Postharvest Biol. Technol., 126, 1-14.

Imahori, Y., Takemura, M. and Bai J. (2008) Chilling-induced oxidative stress and antioxidant responses in mume (Prunusmume) fruit during low temperature storage. Postharvest Biol. Technol., 49, 54-60.

Jitthum, A., Wongs-Aree, C. and Kanlayanarat, S. (2002) Effect of heat treatment and calcium chloride on chilling injury of Archrassapota Linn. Agric. Sci. J., 33, 122-126.
Kou, X.-H., Guo, W.-1., Guo, R.-z., Li, X.-y. andXue, Z.-h. (2014) Effects of chitosan, calcium chloride, and pullulan coating treatments on antioxidant activity in Pear cv. "Huang guan" during storage.Food Bioprocess Technol.,7, 671-681.

Koukounaras, A., Diamantidis, G. and Sfakiotakis, E. (2008) The effect of heat treatment on quality retention of fresh-cut peach.Postharvest Biol. Technol.,48, 30-36.

Lamikanra, O. and Watson, M.A. (2007) Mild heat and calcium treatment effects on freshcut cantaloupe melon during storage.Food Chem.,102, 1383-1388.

Lata, D., Aftab, M.A., Homa, F., Ahmad, M.S. and Siddiqui, M.W. (2018) Effect of ecosafe compounds on postharvest quality preservation of papaya (Carica papaya L.).A ctaPhysiologiaePlantarum,40, 1-8.

Lester, G.E and Grusak. M.A. (1999) Postharvest application of calcium and magnesium to Honeydew and Netted muskmelons: Effects on tissue ion concentrations, quality and senescence.J. Amer. Soc. Hort. Sci., 124, $545-$ 552.

Lima, M.A. C-de, Alves, R.E., Assis, J.S., Filgueiras, H.A.C., Costa, J.T.A. and deAssis, J.S. (2000) Quality, phenols and oxidative enzymes of 'Italia' grape under calcium influence, during ripening.PesquisaAgropecuaria-Brasileira, 35, 2493-2499.

Liu, H., Chen, F., Yang, H., Yao, Y., Gong, X., Xin, Y. and Ding, C. (2009) Effect of calcium treatment on nanostructure of chelate-soluble pectin and physicochemical and textural properties of apricot fruits. Food Res. Int., 42, 1131-1140.

Maheshwari, R., Mohan, L., Malhotra, J., Updhuary, B. and Rani, B. (2014) Invigorating efficacy of Cucumissativus for healthcare \& radiance. IJCPS, 2, 737-744.

Manjunatha, M. and Anurag, R.K. (2014) Effect of modified atmosphere packaging and storage conditions on quality characteristics of cucumber. J. Food Sci. Technol., 51, 34703475 . 
Minorsky, P.V. (1985) An heuristic hypothesis of chilling injury in plants: a role for calcium as the primary physiological transducer of injury. Plant Cell Environ., 8, 75-94.

Moradinezhad, F. and Khayyat, M. (2014) Effects of intermittent warming and prestorage treatments (hot water, salicylic acid, calcium chloride) on postharvest life of pomegranate fruit cv. 'Shishe-Kab' during long-term cold storage., 1, 43-51.

Murad, H. and Nyc, M.A. (2016) Evaluating the potential benefits of cucumbers for improved health and skin care.J. Aging Res. Clin. Int. J. Hort. Sci. Technol. Practice, 5, 139-141.

Nasef, I.N. (2018) Short hot water as safe treatment induces chilling tolerance and antioxidant enzymes, prevents decay and maintains quality of cold-stored cucumbers. Postharvest Biol. Technol., 138, 1-10

Pandey, V.P., Awasthi, M.,Singh, S., Tiwari, S. and Dwivedi, U.N. (2017) A comprehensive review on function and application of plant peroxidases.Biochem.Anal.Biochem., 6, 1-16.

Passardi, F., Cosio, C., Penel, C. and Dunand, C. (2005) Peroxidases have more functions than a Swiss army knife.Plant Cell Rep., 24, 255265.

Penel, C., Cutsem, P.V. and Greppin, H. (1999) Interactions of a plant peroxidase with oligogalacturonidesin the presence of calcium ions. Phytochem., 51, 193-198.

Pila, N., Gol, N.B. and Rao, T.V.R. (2010) Effect of post harvest treatments on physicochemical characteristics and shelf life of tomato (Lycopersiconesculentum Mill.) fruits during storage.Am-Euras. J. Agric. Environ. Sci., 9, 470-479.

Rabiei, V., Es-haghi, S., Aazami, M.A. and Sharafi, Y. (2011a) Combined effects of hot air and calcium chloride on quality and antioxidant enzymes activity in 'red delicious' apple fruits. J. Med. Plant. Res., 5, 4954-4961.

Rabiei, V., Shirzadeh, E., Sharafi, Y. and Mortazavi, N. (2011b) Effects of postharvest applications of calcium nitrate and acetate on quality and shelf-life improvement of "Jonagold" apple fruit. J. Med. Plant. Res., 5, 4912-4917.
Rahman, M.U., Sajid, M., Rab, A., Ali, S., Shahid, M.O., Alam, A., Israr, M. and Ahmad, I. (2016) Impact of calcium chloride concentrations and storage duration on quality attributes of peach (Prunuspersica). Russian Agric. Sci., 42, 130136.

Rao, T.V. R., Gol, N.B. and Shah, K.K. (2011) Effect of postharvest treatments and storage temperatures on the quality and shelf life of sweet pepper (Capsicum annuum L.). Scientia Hort., 132, 18-26.

Sadasivam, S. and Manickam, A. (1991) Biochemical Methods for Agricultural Sciences, Wiley Eastern Limited, New Dellhi and Tamil Nadu Agricultural University, Coimbatore, pp. 5-6.

Safizadeh, M.R., Rahemi, M. and Aminlari, M. (2007) Effect of postharvest calcium and hotwater dip treatments on catalase, peroxidase and superoxide dismutase in chilled Lisbon lemon fruit. Int. J. Agri. Res., 2, 440-449.

Sala, J.M. and Lafuente, M.T. (1999) Catalase in the heat-induced chilling tolerance of coldstored hybrid fortune mandarin fruits. J. Agric. Food Chem., 47, 2410-2414.

Sala, J.M. and Lafuente, M.T. (2000) Catalase enzyme activity is related to tolerance of mandarin fruits to chilling. Postharvest Biol. Technol., 20, 81-89.

Sams, C.E. and Conway, W.S. (1993) Postharvest calcium infiltration improves fresh and processing quality of apples. Acta Hort., 326, 123-130.

Shafiee, M., Taghavi, T.S. and Babalar, M. (2010) Addition of salicylic acid to nutrient solution combined with postharvest treatments (hot water, salicylic acid, and calcium dipping) improved postharvest fruit quality of strawberry. Scientia Hort., 124, 40-45.

Shahkoomahally, S. and Ramezanian, A. (2015) Hot water combined with calcium treatment improves physical and physicochemical attributes of kiwifruit (Actinidiadeliciosa cv. Hayward) during storage. HortScience, 50, 412-415.

Shirzadeh, E., Rabiei1, V. and Sharafi, Y. (2011) Effect of calcium chloride $\left(\mathrm{CaCl}_{2}\right)$ on postharvest quality of apple fruits. Afr. J. Agric. Res., 6, 5139-5143.

Egypt. J. Hort. Vol. 46, No.1 (2019) 
Silveira, A.C., Aguayo, E., Chisari, M. and Artés, F. (2011) Calcium salts and heat treatment for quality retention of fresh-cut 'Galia' melon. Postharvest Biol. Technol., 62, 77-84.

Suslow, T.V. and Cantwell, M. (1998) Cucumber Perishables Handling Quarterly, 93. University of California, Davis, CA, pp. 15-16.

Toivonen, P.M.A. (2009) Benefits of combined treatment approaches to maintaining fruit and vegetable quality. Fresh produce, 3 (Special Issue 1), 58-64.

Trail, M.A., Wahem, I.A. and Bizri, J.N. (1992) Snap bean quality changed minimally when stored in low density polyolefin film package.J. Food Sci., 57, 977-979.

Tsuchida, H., Kozukue, N., Han, G-P., Choi, S-H., Levin, C.E. and Friedman, M. (2010) Lowtemperature storage of cucumbers induces changes in the organic acid content and in citrate synthase activity. Postharvest Biol. Technol., 58, 129-134.
Wang, C.Y. (1998) Heat treatment affects postharvest quality of kale and collard, but not of Brussels sprouts. HortScience, 33, 881-883.

Wu, B., Guo, Q., Wang, G-X., Peng, X-y., Wang, J-d.and Che, F-b. (2015) Effects of different postharvest treatments on the physiology and quality of 'Xiaobai' apricots at room temperature. J. Food Sci. Technol., 52, $2247-$ 2255.

Xing, Y., Li, X., Xu, Q., Yun, J., Lu, Y. and Tang, Y. (2011) Effects of chitosan coating enriched with cinnamon oil on qualitative properties of sweet pepper (Capsicum annuum L.). Food Chem., 124, 1443-1450.

(Received 04/12/2018; accepted 27/01/2019)

\section{المحافظة على جودة الخيار المخزن تحت إجهاد البرودة وفترة البقاء فى ظروف الغرفة

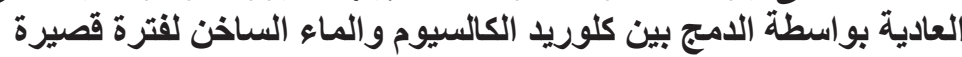 \\ إبر اهيم ناصف ناصف \\ قسم البساتين ـ كلبة الزر اعة ـ جامعة قناة السويس ـ الإسماعبلية ـ مصر.}

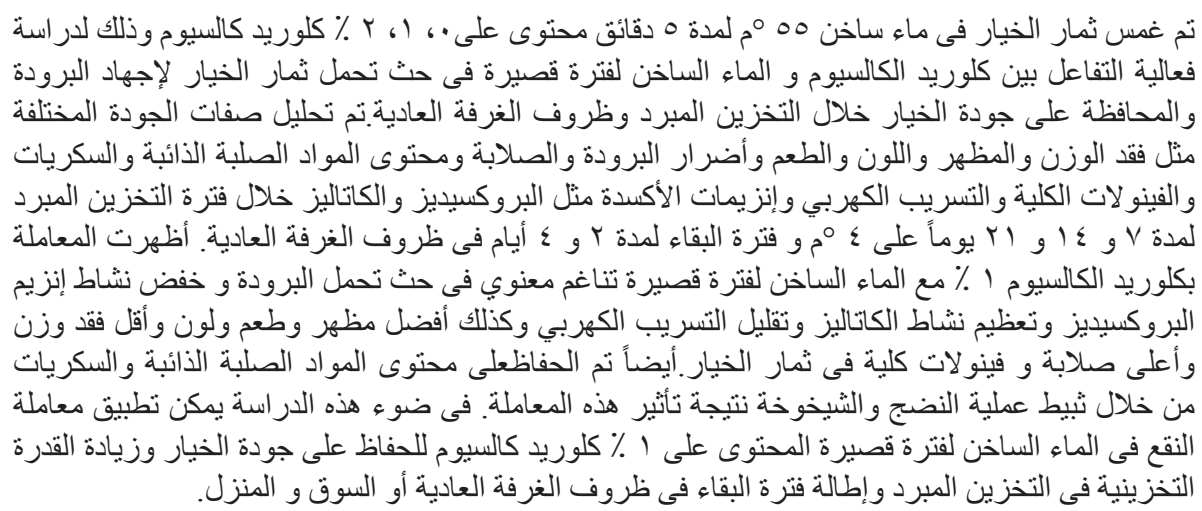

